BNL-114204-2017-JA

\title{
In Situ Investigation of Methane Dry Reforming on Metal/Ceria(111) Surfaces: Metal-Support Interactions and C-H Bond Activation at Low Temperature
}

\author{
Z. Liu \\ Submitted to Angewandte Chemie
}

August 2017

Chemistry Department

Brookhaven National Laboratory

\author{
U.S. Department of Energy \\ USDOE Office of Science (SC), \\ Basic Energy Sciences (BES) (SC-22)
}




\section{DISCLAIMER}

This report was prepared as an account of work sponsored by an agency of the United States Government. Neither the United States Government nor any agency thereof, nor any of their employees, nor any of their contractors, subcontractors, or their employees, makes any warranty, express or implied, or assumes any legal liability or responsibility for the accuracy, completeness, or any third party's use or the results of such use of any information, apparatus, product, or process disclosed, or represents that its use would not infringe privately owned rights. Reference herein to any specific commercial product, process, or service by trade name, trademark, manufacturer, or otherwise, does not necessarily constitute or imply its endorsement, recommendation, or favoring by the United States Government or any agency thereof or its contractors or subcontractors. The views and opinions of authors expressed herein do not necessarily state or reflect those of the United States Government or any agency thereof. 


\title{
In Situ Investigation of Methane Dry Reforming on Metal/Ceria(111) Surfaces: Metal-Support Interactions and C-H Bond Activation at Low Temperature
}

\author{
Zongyuan Liu, ${ }^{[a]}$ Pablo Lustemberg, ${ }^{[b]}$ Ramón A. Gutiérrez, ${ }^{[c]}$ John J. Carey, ${ }^{[d]}$ Robert M. Palomino, \\ ${ }^{[a]}$ Mykhailo Vorokhta, ${ }^{[\mathrm{e}]}$ David C. Grinter, ${ }^{[\mathrm{a}]}$ Pedro J. Ramírez, ${ }^{[\mathrm{c}]}$ Vladimír Matolín, ${ }^{[\mathrm{e}]}$ Michael Nolan, ${ }^{[\mathrm{d}]}$ \\ M. Verónica Ganduglia-Pirovano, ${ }^{\text {[f] }}$ Sanjaya D. Senanayake, ${ }^{*[a]}$ and José A. Rodriguez ${ }^{*[a]}$
}

\begin{abstract}
Studies with a series of $\mathrm{M}-\mathrm{CeO}_{2}(111)\{\mathrm{M}=\mathrm{Co}, \mathrm{Ni}, \mathrm{Cu}\}$ surfaces indicate that metal-oxide interactions can play a very important role for the activation of methane and its reforming with $\mathrm{CO}_{2}$ at relatively low temperatures $(600-700 \mathrm{~K})$. Among the systems examined, $\mathrm{Co}-\mathrm{CeO}_{2}(111)$ exhibits the best performance and $\mathrm{Cu}$ $\mathrm{CeO}_{2}(111)$ has negligible activity. Experiments using ambient pressure XPS indicate that methane dissociates on $\mathrm{Co}-\mathrm{CeO}_{2}(111)$, at temperatures as low as $300 \mathrm{~K}$, generating $\mathrm{CH}_{\mathrm{x}}$ and $\mathrm{CO}_{\mathrm{x}}$ species on the catalyst surface. The results of density-functional calculations show a reduction in the methane activation barrier from $1.07 \mathrm{eV}$ on $\mathrm{Co}(0001)$ to $0.87 \mathrm{eV}$ on $\mathrm{Co}^{2+} / \mathrm{CeO}_{2}(111)$, and to only $0.05 \mathrm{eV}$ on $\mathrm{Co}^{0} / \mathrm{CeO}_{2-\mathrm{x}}(111)$. At $700 \mathrm{~K}$, under methane dry reforming conditions, $\mathrm{CO}_{2}$ dissociates on the oxide surface and a catalytic cycle is established without coke deposition. A significant part of the $\mathrm{CH}_{\mathrm{x}}$ formed on the $\mathrm{Co}^{0} / \mathrm{CeO}_{2-\mathrm{x}}(111)$ catalyst recombines to yield ethane or ethylene.
\end{abstract}

Natural gas can transform the energy landscape of the world since it is a cheap and abundant fuel stock and a good source of carbon for the chemical industry. $\mathrm{CH}_{4}$ is the primary component of natural gas but is difficult to convert it to upgraded fuels or chemicals due to the strength of the $\mathrm{C}-\mathrm{H}$ bonds in the molecule $(104 \mathrm{kcal} / \mathrm{mol})$ and its non-polar nature ${ }^{[1]}$ Enabling low-

[a] Dr Z. Liu, Dr R. Palomino, Dr D. Grinter, Dr S.D. Senanayake, Dr J.A. Rodriguez

Chemistry Department, Brookhaven National Laboratory

Upton, NY 11973 (USA)

E-mail: ssenanay@bnl.gov

E-Mail: rodrigez@bnl.gov

[b] Dr P. Lustemberg

Instituto de Fisica Rosario (IFIR), CONICET (Argentina)

[c] MSc R.A. Gutierrez, Prof P.J. Ramírez

Facultad de Ciencias, Universidad Central de Venezuela, Caracas 1020-A (Venezuela)

[d] Dr. J.J. Carey, Dr. M. Nolan

Tyndall National Institute, University College Cork, Lee Maltings, Cork (Ireland)

[e] Dr M. Vorokhta, Prof V. Matolin

Department of Surface and Plasma Science, Faculty of Mathematics and Physics, Charles University, Prague, (Czech Republic)

[f] Dr M.V. Ganduglia-Pirovano

Instituto de Catálisis y Petroleoquímica, CSIC

C/Marie Curie 2, 28049 Madrid (Spain)

E-mail:vgp@icp.csic.es

Supporting information for this article is given via a link at the end of the document

temperature activation of methane is a major technological objective. It is known that enzymes such as the methane monooxygenase and some copper- and zinc-based inorganic compounds can activate $\mathrm{C}-\mathrm{H}$ bonds near room temperature. ${ }^{[2-4]}$
In recent studies, we found that a $\mathrm{Ni}^{2+} / \mathrm{CeO}_{2}$ (111) system activates $\mathrm{CH}_{4}$ at room temperature as a consequence of metalsupport interactions. ${ }^{[5,6]}$ The methane reforming with $\mathrm{CO}_{2}(\mathrm{DRM}$; $\mathrm{CH}_{4}+\mathrm{CO}_{2} \rightarrow 2 \mathrm{CO}+2 \mathrm{H}_{2}$ ) then takes place at a moderate temperature of about $700 \mathrm{~K}$. Over this surface, $\mathrm{Ni}$ and $\mathrm{O}$ sites of ceria work in a cooperative way during the dissociation of the first $\mathrm{C}-\mathrm{H}$ bond in methane. Can this useful phenomenon be seen with other admetal-ceria combinations? In this article we compare the behavior of $\mathrm{Co}, \mathrm{Ni}$ and $\mathrm{Cu}$ on $\mathrm{CeO}_{2}(111)$ using ambient-pressure X-ray photoelectron spectroscopy (AP-XPS), kinetic testing, and theoretical calculations based on densityfunctional theory.

The deposition of small amounts of Co (<0.3 ML) on a $\mathrm{CeO}_{2}(111)$ film at $300 \mathrm{~K}$ produced a partial reduction of the oxide surface and adsorbed $\mathrm{Co} / \mathrm{CoO}_{x}$ species (Figure $\mathrm{S} 1$ in Supporting Information). Upon annealing from 300 to $700 \mathrm{~K}$, most of the $\mathrm{Co}^{0}$ transformed into $\mathrm{Co}^{2+}$ (Figure S2). This particular type of metal-oxide surface was exposed to methane at 300,500 and $700 \mathrm{~K}$. Figure 1 shows C 1s XPS spectra collected before and after exposing a $\mathrm{Co} / \mathrm{CeO}_{2}(111)$ surface to 1 Torr of methane at $300 \mathrm{~K}$ for 5 minutes. The strong peak near $285 \mathrm{eV}$ can be attributed to $\mathrm{CH}_{\mathrm{x}}$ groups formed by the partial

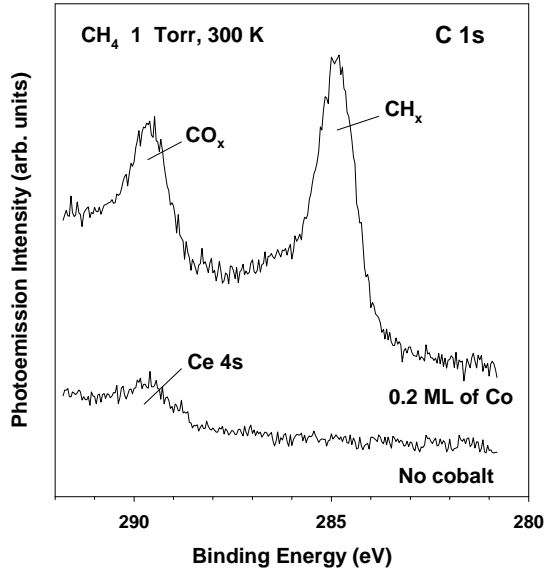

Figure 1. $\mathrm{C}$ 1s XPS spectra collected before and after exposing a $\mathrm{CeO}_{2}(111)$ surface containing $0.2 \mathrm{ML}$ of Co to 1 Torr of methane at $300 \mathrm{~K}$ for 5 minutes.

dissociation of methane on the metal/oxide interface..$^{[5,6]}$ This peak was not seen when a pure $\mathrm{CeO}_{2}(111)$ substrate was exposed to $\mathrm{CH}_{4}$ at $300 \mathrm{~K}$. In Figure 1 there is a second strong peak near $289.5 \mathrm{eV}$. This likely corresponds to a $\mathrm{CO}_{x}$ species. ${ }^{[5,6]}$ Some of the $\mathrm{CH}_{4}$ molecules fully dissociated producing $\mathrm{C}$ atoms that eventually reacted with oxygen atoms of 
the ceria to yield $\mathrm{CO}_{x}$ species. The intensity of the $\mathrm{C} 1 \mathrm{~s}$ peak for the $\mathrm{CH}_{\mathrm{x}}$ species increased with Co coverage up to 0.15-0.2 ML, and then decreased at higher admetal coverages. Thus, small clusters of $\mathrm{Co}$ on ceria are the best for for $\mathrm{C}-\mathrm{H}$ bond activation. The dissociative adsorption of methane on the $\mathrm{Co}^{2+} / \mathrm{CeO}_{2}(111)$ surface at room temperature did not induce a change in the oxidation state of $\mathrm{Co}^{2+}$ or $\mathrm{Ce}^{4+}$. Such changes were only seen when the dosing of methane was done at temperatures of 500 and $700 \mathrm{~K}$.

Figure 2 displays $\mathrm{Ce} 3 \mathrm{~d}$ and Co $2 \mathrm{p}$ AP-XPS spectra recorded while exposing a $\mathrm{CeO}_{2}(111)$ surface with $0.2 \mathrm{ML}$ of $\mathrm{Co}$ to $50 \mathrm{mTorr}$ of $\mathrm{CH}_{4}$ at different temperatures. Both ceria and $\mathrm{Co}^{2+}$ species undergo reduction at $500-700 \mathrm{~K}$ as indicated by the emergence of $\mathrm{Ce}^{3+}$ and $\mathrm{Co}^{0}$ features. Once the first hydrogen is removed from the reactant molecule, a quick $\mathrm{CH}_{3} \rightarrow \mathrm{CH}_{2} \rightarrow \mathrm{CH}$ $\rightarrow \mathrm{C}$ transformation occurs on the surface and oxygen atoms from the sample react to form $\mathrm{CO}$ and $\mathrm{H}_{2} \mathrm{O}$ gas.

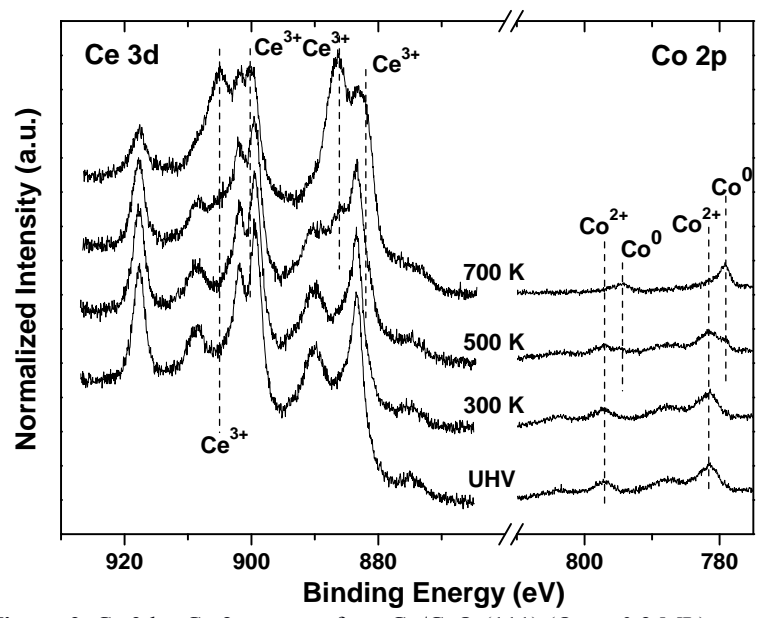

Figure 2. $\mathrm{Ce} 3 \mathrm{~d}+\mathrm{Co} 2 \mathrm{p}$ spectra for a $\mathrm{Co} / \mathrm{CeO}_{2}(111)\left(\Theta_{\mathrm{Co}} \approx 0.2 \mathrm{ML}\right)$ surface under $50 \mathrm{mTorr}^{\circ} \mathrm{CH}_{4}$ at 300,500 and $700 \mathrm{~K}$.

Similar experiments to those shown in Figures 1 and 2 were performed for $\mathrm{Cu} / \mathrm{CeO}_{2}(111)$. The results of XPS and Auger spectroscopy indicate that the interaction of $\mathrm{Cu}$ with $\mathrm{CeO}_{2}(111)$, Figures S3 and S4, is not as strong as that seen for Co. The dissociation of methane on $\mathrm{Cu} / \mathrm{CeO}_{2}(111)$ surfaces was negligible at temperatures between 300 and $700 \mathrm{~K}$ (Figure S5). In this aspect, the behavior of these surfaces is very similar to that found for clean $\mathrm{CeO}_{2}(111){ }^{[5,6]}$ In Figure 3, we compare the reduction of ceria (i.e. formation of $\mathrm{Ce}^{3+}$ ) after dosing methane to $\mathrm{Co}-\mathrm{CeO}_{2}(111), \mathrm{Cu}-\mathrm{CeO}_{2}(111)$ and a $\mathrm{Ni}-\mathrm{CeO}_{2}(111)$ system examined in a previous study. ${ }^{[5]}$ In the temperature range of $500-700 \mathrm{~K}, \mathrm{Co} / \mathrm{CeO}_{2}(111)$ reacts better with methane than $\mathrm{Ni} / \mathrm{CeO}_{2}(111)$ or $\mathrm{Cu} / \mathrm{CeO}_{2}(111)$. As we will see below, the partial reduction of ceria is important for the activation of $\mathrm{CO}_{2}$ and closing the catalytic cycle for methane dry reforming.

In the case of $\mathrm{Co} / \mathrm{CeO}_{2}(111)$, catalytic activity for methane dry reforming and $\mathrm{C} 2$ (ethane/ethylene) production was seen at $650 \mathrm{~K}$ (Figure 4). Clean $\mathrm{CeO}_{2}$ (111) did not display significant catalytic activity. However, the catalytic activity substantially increased when Co was added, reaching a maximum for the generation of $\mathrm{CO} / \mathrm{H}_{2}$ at a coverage of $\sim 0.15 \mathrm{ML}$. A maximum for the production of ethane/ethylene was seen at a Co coverage of $0.1 \mathrm{ML}$. At these small Co coverages, the $\mathrm{Co} / \mathrm{CeO}_{2}(111)$ system had no problem dissociating $\mathrm{CH}_{4}$ (Figures 1-3). The $\mathrm{CH}_{3}$ groups generated on the surface underwent full decomposition to yield syngas or formed carbon-carbon bonds to produce ethane or ethylene. In Figure 4, the hydrogen is produced by methane dry

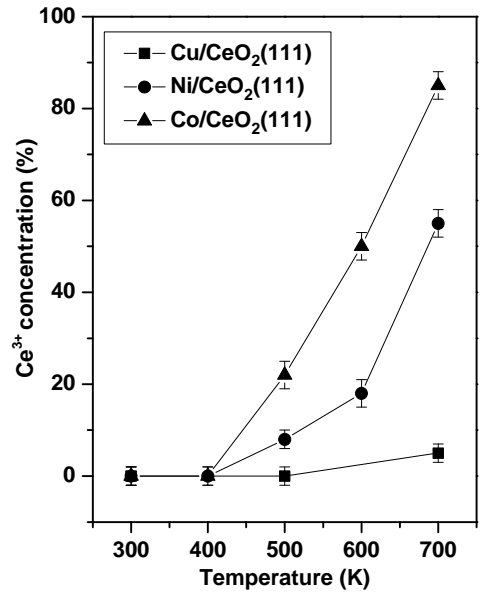

Figure 3. $\mathrm{Ce}^{3+}$ concentration measured in XPS as a function of temperature under reaction conditions (i.e. exposure to $50 \mathrm{mTorr}$ of methane) on ceria precovered with $\sim 0.2 \mathrm{ML}$ of $\mathrm{Co}, \mathrm{Ni}$ or $\mathrm{Cu}$.

reforming or by the generation of hydrocarbons $\left(2 \mathrm{CH}_{4} \rightarrow\right.$ $\left.\mathrm{C}_{2} \mathrm{H}_{6} / \mathrm{C}_{2} \mathrm{H}_{4}+\mathrm{nH}_{2}\right){ }^{[7,8]} \mathrm{CO}$ and $\mathrm{C}_{2} \mathrm{H}_{4}$ also can be obtained through the reaction: $2 \mathrm{CH}_{4}+2 \mathrm{CO}_{2} \rightarrow 2 \mathrm{CO}+\mathrm{C}_{2} \mathrm{H}_{4}+2 \mathrm{H}_{2} \mathrm{O}$. At the maximum of catalytic activity in Figure 4 , one can estimate a turnover frequency (TOF) of 6-7 molecules/Co atom $\cdot \mathrm{sec}$ for methane dry reforming. At Co coverages above $0.2 \mathrm{ML}$, there

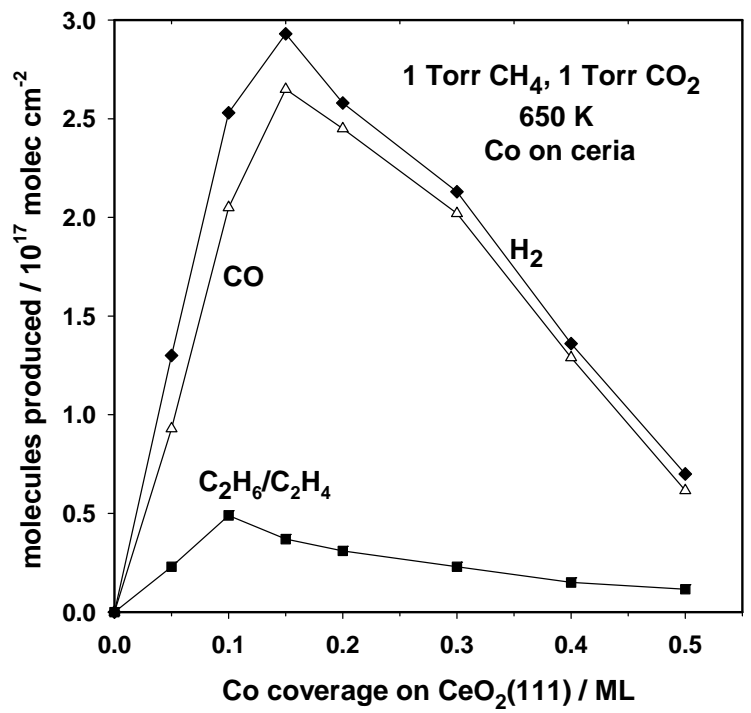

Figure 4. Catalytic activity for methane dry reforming and ethane production on Co-ceria catalysts as a function of Co coverage. The figure reports the amount of $\mathrm{CO} / \mathrm{H}_{2}$ and ethane/ethylene formed after exposing the Co-ceria surfaces to 1 Torr of $\mathrm{CH}_{4}$ and 1 Torr of $\mathrm{CO}_{2}$ at $650 \mathrm{~K}$ for 5 minutes.

was a steady decline in the catalytic activity. At the same time, postreaction characterization of the catalysts with XPS showed an increase in the amount of atomic carbon present in the surface (Figure S6). This carbon could eventually lead to the formation of coke and catalyst deactivation. Thus, the optimum Co coverage is below $0.2 \mathrm{ML}$, when the interactions with the oxide support are important and the strength and number of the Co-Co interactions is limited. 
AP-XPS was used to study the chemical changes in the best $\mathrm{Co} / \mathrm{CeO}_{2}(111)$ catalyst under reaction conditions. Figure 5 shows Ce $3 \mathrm{~d}$ and Co $2 \mathrm{p}$ spectra collected while the catalyst is exposed to $\mathrm{CH}_{4}$ or a mixture of $\mathrm{CH}_{4} / \mathrm{CO}_{2}$ at $700 \mathrm{~K}$. Under pure methane one sees a surface with $\mathrm{Co}^{0}$ and strong peaks for $\mathrm{Ce}^{3+}$. The addition of $\mathrm{CO}_{2}$ to the reactant gas leads to a weak reoxidation of $\mathrm{Co}$ and a substantial $\mathrm{Ce}^{3+} \rightarrow \mathrm{Ce}^{4+}$ conversion. Two reaction paths are possible for the re-oxidation of the $\mathrm{Ce}^{3+}$ in the support: $\mathrm{CO}_{2}(\mathrm{~g})+\mathrm{Vac} \rightarrow \mathrm{CO}(\mathrm{g})+\mathrm{O}$-oxide, or $\mathrm{CO}_{2}(\mathrm{~g})+$ $\mathrm{H}(\mathrm{a})+\mathrm{Vac} \rightarrow \mathrm{HOCO}(\mathrm{a}) \rightarrow \mathrm{HO}-\mathrm{Vac}+\mathrm{CO}(\mathrm{g})$ and $\mathrm{HO}-\mathrm{Vac} \rightarrow \mathrm{O}-$ oxide $+\mathrm{H}(\mathrm{a})$. Both of them could close the catalytic cycle for methane dry reforming after the process: $\mathrm{CH}_{4}(\mathrm{~g}) \rightarrow \mathrm{C}(\mathrm{a})+$ $4 \mathrm{H}(\mathrm{a}) ; \mathrm{C}(\mathrm{a})+\mathrm{O}$-oxide $\rightarrow \mathrm{CO}(\mathrm{g})+\mathrm{Vac}$

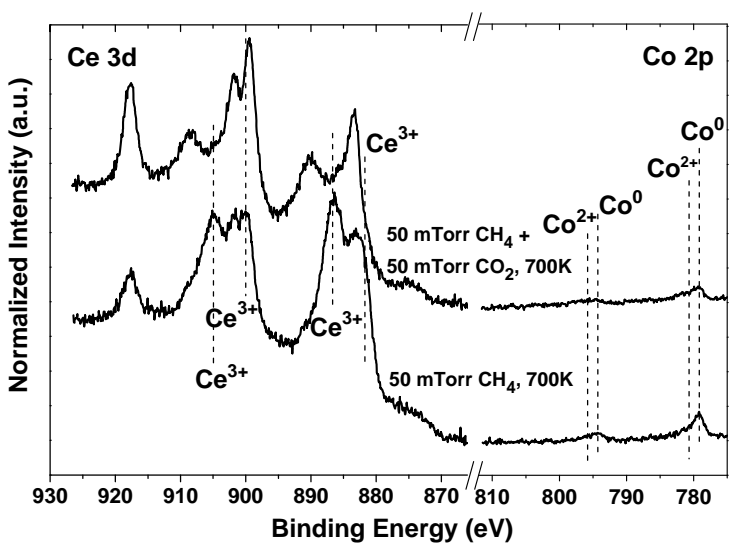

Figure 5. Ce $3 d+$ Co $2 p$ XPS spectra of the surface at $700 \mathrm{~K}$ under $50 \mathrm{mTor}$ of methane w/o the addition of $50 \mathrm{mTorr} \mathrm{CO}_{2}$, The scale of the Co $2 p$ region has been multiplied by a factor of $3\left(\theta_{\mathrm{Co}_{0}} \sim 0.2 \mathrm{ML}\right)$.

Figure 6 compares the catalytic activity for methane dry reforming of $\mathrm{Co}-, \mathrm{Cu}$ - and $\mathrm{Ni}-\mathrm{CeO}_{2}(111)^{[6]}$. The surface with Co is clearly the best catalyst, in agreement with the trends seen in Figure 3 for the activation of pure methane. Among these systems, $\mathrm{Co}-\mathrm{CeO}_{2}(111)$ is the only one able to catalyze the $2 \mathrm{CH}_{4} \rightarrow \mathrm{C}_{2} \mathrm{H}_{\mathrm{x}}+\{(8-\mathrm{x}) / 2\} \mathrm{H}_{2}$ reaction $(\mathrm{x}=4,6)$. The negligible catalytic activity of $\mathrm{Cu} / \mathrm{CeO}_{2}(111)$ results from a very poor reaction with $\mathrm{CH}_{4}$ without the generation of the $\mathrm{Ce}^{3+}$ sites necessary for the activation of $\mathrm{CO}_{2}$, as indicated in Figure 3 , which shows that reducibility increases in the order $\mathrm{Cu}<\mathrm{Ni}<\mathrm{Co}$ In a set of experiments, we deposited small Co coverages (5-10 $w t \%)$ on a ceria powder and tested the catalyst activity for DRM in a flow reactor at temperatures between 700 and $975 \mathrm{~K}$. The powder system did not show signs for deactivation and the conversion of methane through dry reforming was always close to that determined by equilibrium thermodynamics. ${ }^{[\mathrm{b}]}$ These results are in agreement with the behaviour seen for $\mathrm{Co} / \mathrm{CeO}_{2}(111)$ at $700 \mathrm{~K}$.

Methane decomposition is frequently cited as the most difficult step for the DRM process. ${ }^{[7,8]}$ Here, we apply the spinpolarized $\mathrm{DFT}+\mathrm{U}$ approach to investigate the dissociative adsorption of $\mathrm{CH}_{4}$ on $\mathrm{Co}$ and $\mathrm{Cu}$ nanoparticles deposited on stoichiometric and reduced cerium oxide surfaces, plus the extended $\mathrm{Co}(0001)$, $\mathrm{Co}(111)$ and $\mathrm{Cu}(111)$ surfaces. Results will be compared to those recently obtained for Ni-ceria systems. ${ }^{[5,6]}$ The metal-ceria surfaces used for the experiments are quite complex. $\mathrm{Co} / \mathrm{CeO}_{2}(111)$ displays high activity for methane dissociation at low metal coverages with Co atoms in close contact with the ceria support in a 2+ oxidation state, whereas $\mathrm{Cu} / \mathrm{CeO}_{2}(111)$ is not active, with $\mathrm{Cu}^{1+}$ atoms aggregating to form larger metallic nanoparticles. Thus, we model these systems using single $\mathrm{Co}$ atoms and small tetrahedral $\mathrm{Cu}_{4}$

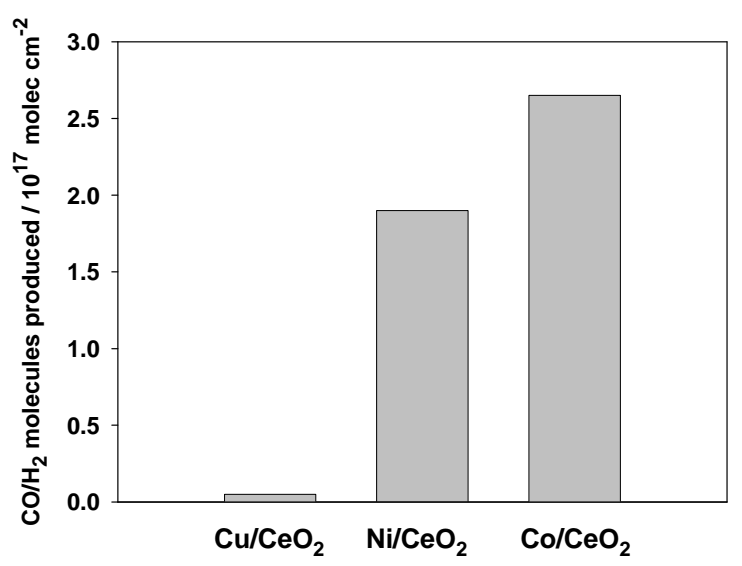

Figure 6. Catalytic activity for methane dry reforming on $\mathrm{Cu}-$, $\mathrm{Ni}-$, $\mathrm{Co}-\mathrm{ceria}$ catalysts $\left(\theta_{\text {Admetal }} \sim 0.15 \mathrm{ML}\right)$. The figure reports the amount of $\mathrm{CO} / \mathrm{H}_{2}$ formed after exposing the catalysts to 1 Torr of $\mathrm{CH}_{4}$ and $1 \mathrm{Torr}$ of $\mathrm{CO}_{2}$ at $650 \mathrm{~K}$ for 5 minutes.

clusters on $\mathrm{CeO}_{2}(111)$, Figure $\mathrm{S} 7$. We found that $\mathrm{Co}^{2+}$ species $\left(3 d^{7}\right)$ adsorb most favorably at O-hollow sites in $\mathrm{CeO}_{2}(111)$, with the transfer of two electrons to the reducible support. $\mathrm{Cu}$ atoms transfer only one electron, yielding $\mathrm{Cu}^{1+}$ species $\left(3 \mathrm{~d}^{10}\right)$. The $\mathrm{Cu}_{4}$ species also reduce the support, with the formation of two $\mathrm{Ce}^{3+}$. The $\mathrm{CeO}_{2}(111)$ supported $\mathrm{Co}_{1}$ and $\mathrm{Cu}_{4}$ species behave similarly to the corresponding $\mathrm{Ni}_{1}$ and $\mathrm{Ni}_{4}$ ones. ${ }^{[5,6,9]}$ Moreover, lowloaded $\mathrm{Co} / \mathrm{CeO}_{2-x}(111)$ with metallic cobalt, is the active phase for methane dry reforming, which will be modeled using single metal $\mathrm{Co}$ atoms on $\mathrm{Ce}_{2} \mathrm{O}_{3}(0001)$ (Figure S7). Hence, these $\mathrm{M}$ ceria $\{\mathrm{M}=\mathrm{Co}, \mathrm{Cu}\}$ model surfaces mimic the essential features of the experimental catalysts as seen in the XPS data shown in Figures 3 and 5 .

The molecular binding of methane to $\mathrm{Co}$ or $\mathrm{Cu}$ surfaces is very weak and dissociation, $\mathrm{CH}_{4}(\mathrm{a}) \rightarrow \mathrm{CH}_{3}(\mathrm{a})+\mathrm{H}(\mathrm{a})$, is difficult due to large energy barriers. ${ }^{[10,11]}$ Our calculated barriers are 1.07 and $1.64 \mathrm{eV}$ (Figure S8), respectively, in agreement with previous studies. ${ }^{[10,11]}$ This is similar to $\mathrm{Ni}(111)$ with a barrier of about $0.9-1.1 \mathrm{eV}^{[5,12]}$ The molecular binding of $\mathrm{CH}_{4}$ to $\mathrm{Co}^{2+}$ and $\mathrm{Cu}_{4}$ species on $\mathrm{CeO}_{2}(111)$ lies within the 0.1-0.2 eV range (Figures $7 \mathrm{a}$ and $\mathrm{S} 9$ ). On the $\mathrm{Cu}_{4} / \mathrm{CeO}_{2}(111)$ surface, similar to $\mathrm{Cu}(111)$, methane dissociation is hindered by a large energy barrier of $1.45 \mathrm{eV}$. This is consistent with the negligible methane dissociation observed for $\mathrm{Cu}$-ceria systems at room temperature. However, on $\mathrm{Co}_{1} / \mathrm{CeO}_{2}(111)$, the barrier is reduced from 1.07 to $0.87 \mathrm{eV}$, as compared to $\mathrm{Co}(0001)$ (and from $1.02 \mathrm{eV}$ if fcc $\mathrm{Co}(111)$ is considered, Figure S8). Therefore, the energy barrier for ceria supported small Co nanoparticles is accessible at lower temperatures than on the extended metal surface and methane dissociation is expected to occur, in agreement with the experiments shown in Figure 1. Here, metal and support work in a cooperative way in the dissociation of the $\mathrm{C}-\mathrm{H}$ bond. Note that the final states shown in Figure $7 a$ do not necessarily correspond to the lowest energy structures of the dissociated methane (Figure S9), but to local minima geometrically close to the transition state structures.

Upon increasing oxygen removal from the ceria support by reaction with methane, the $\mathrm{Co}^{2+}$ species gradually recover their metallic state. Chemisorbed methane molecules on both $\mathrm{M}^{0} / \mathrm{Ce}_{2} \mathrm{O}_{3}(0001)\{\mathrm{M}=\mathrm{Co}, \mathrm{Ni}\}$ model systems are more stable than on the corresponding $\mathrm{M}^{2+} / \mathrm{CeO}_{2}(111)$ model systems (Figure 7), and thus the probability of reaction is expected to increase on the actual active dry reforming metal- $\mathrm{CeO}_{2-x}$ catalysts. We observe that the distances between methane and the $\mathrm{M}^{0} / \mathrm{Ce}_{2} \mathrm{O}_{3}(0001)\{\mathrm{M}=\mathrm{Co}$, Ni $\}$ surfaces, as measured by the $\mathrm{C}-\mathrm{M}$ distances, are reduced by approx. 0.6 (Co) to $1.0(\mathrm{Ni}) \AA$ with respect to the same distances in the $\mathrm{M}^{2+} / \mathrm{CeO}_{2}(111)$ systems (Figures S9 and S10). Moreover, $\mathrm{CH}_{4}$ adsorption on the $\mathrm{M} \%$ 
$\mathrm{Ce}_{2} \mathrm{O}_{3}(0001)$ surfaces is aided by substantial hydrogen-metal interactions that are more pronounced compared to the $\mathrm{M}^{2+}$ $\mathrm{CeO}_{2}(111)$ systems;
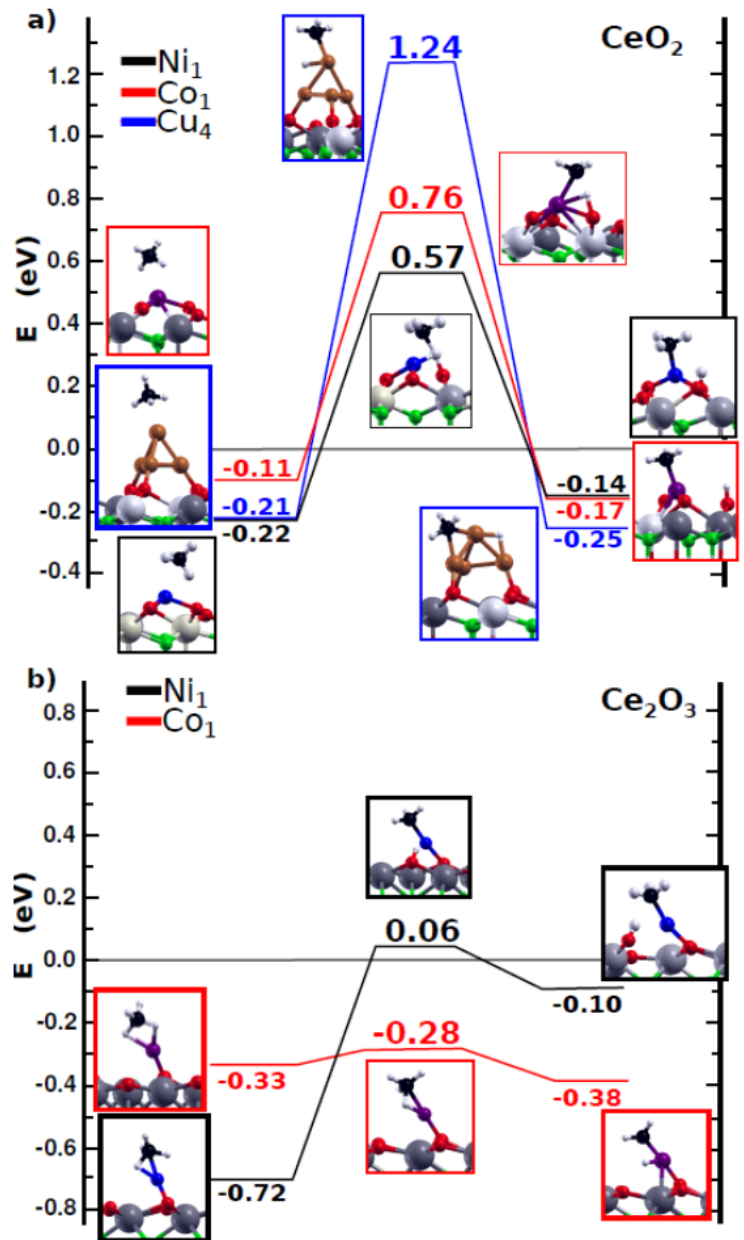

Figure 7. Reaction energy profile for the $\mathrm{CH}_{4} \rightarrow \mathrm{CH}_{3}+\mathrm{H}$ reaction on: a) $\mathrm{Cu}_{4}$ $\mathrm{Co}_{1}$ and $\mathrm{Ni}_{1}$ on $\mathrm{CeO}_{2}(111)$ and b) $\mathrm{Co}_{1}$ and $\mathrm{Ni}_{1}$ on $\mathrm{Ce}_{2} \mathrm{O}_{3}(0001)$. The activation barriers are hardly affected by inclusion of vdW interactions (Figure S14). The structures shown on the left, middle and right of the reaction pathways, correspond to the side views of the molecularly adsorbed, transition and dissociated states, respectively (Supporting information Figures S9 and S10). All energies are referenced to the total energy of $\mathrm{CH} 4(\mathrm{~g})$ and the $\mathrm{M} /$ ceria $\{\mathrm{M}=\mathrm{Co}, \mathrm{Ni}, \mathrm{Cu}\}$ surfaces. Atoms color scheme: $\mathrm{Ni}$ in blue, $\mathrm{Cu}$ in brown, $\mathrm{Co}$ in violet, $\mathrm{Ce}^{3+}$ in grey, $\mathrm{Ce}^{4+}$ in white, surface/subsurface oxygen atoms in red/green. The $\mathrm{CH}_{4}-\mathrm{Ni}^{0} / \mathrm{Ce}_{2} \mathrm{O}_{3}(0001)$ structure is by $0.15 \mathrm{eV}$ more stable than the corresponding one in Ref. 5.

The closer approach to the $\mathrm{M}^{0} / \mathrm{Ce}_{2} \mathrm{O}_{3}(0001)$ surfaces facilitates charge transfer to methane, e.g., the increase in the Bader charge for the $\mathrm{C}$ atom upon $\mathrm{CH}_{4}$ adsorption is 0.03 and 0.16 electrons for $\mathrm{Co}^{2+} / \mathrm{CeO}_{2}(111)$ and $\mathrm{Co}^{0} / \mathrm{Ce}_{2} \mathrm{O}_{3}(0001)$, respectively with respect to the gas-phase $\mathrm{CH}_{4}$ molecule (Table S1). Furthermore, the energy barrier for the dissociative adsorption of methane on $\mathrm{Co}^{\circ} / \mathrm{Ce}_{2} \mathrm{O}_{3}(0001)$ is substantially reduced compared to $\mathrm{Co}^{2+} / \mathrm{CeO}_{2}(111)$, becoming almost negligible $-\mathrm{E}^{\mathrm{a}}=0.05 \mathrm{eV}$. This is not the case for the corresponding Ni-ceria systems for which the barrier remains unchanged $(\sim 0.8 \mathrm{eV})$. We interpret this unique Co behavior by inspecting the transition state structures for the $\mathrm{M}^{0} / \mathrm{Ce}_{2} \mathrm{O}_{3}(0001)\{\mathrm{M}=\mathrm{Co}, \mathrm{Ni}\}$ surfaces (Figure $7 \mathrm{~b}$ ): the marked differences in activation barriers relate to the ability of the metals to form strong $\mathrm{M}-\mathrm{H}$ bonds. Figure $7 \mathrm{~b}$ shows that on $\mathrm{Co}^{0} / \mathrm{Ce}_{2} \mathrm{O}_{3}(0001)$, the Co sites work alone during the dissociation of the first $\mathrm{C}-\mathrm{H}$ bond. By contrast, on $\mathrm{Ni}^{0} / \mathrm{Ce}_{2} \mathrm{O}_{3}(0001), \mathrm{Ni}$ and $\mathrm{O}$ sites work cooperatively. This is also consistent with the calculated adsorption energy for hydrogen atoms on the $\mathrm{M}^{0} / \mathrm{Ce}_{2} \mathrm{O}_{3}(0001)\{\mathrm{M}=\mathrm{Co}, \mathrm{Ni}\}$ surfaces, which is larger by about $0.7 \mathrm{eV}$ on $\mathrm{Co}$ than on $\mathrm{Ni}$ (Figure S12). Thus, both $\mathrm{Co}-$ and $\mathrm{Ni}$-ceria systems are able to cleave $\mathrm{C}-\mathrm{H}$ bonds at room temperature. However, it is only for Co-ceria that as the temperature increases, and methane decomposes and reacts with the $\mathrm{CeO}_{2}$ support, accompanied by the $\mathrm{Co}^{2+} / \mathrm{CeO}_{2} \rightarrow$ $\mathrm{Co}^{0} / \mathrm{CeO}_{2-x}$ transformation, that $\mathrm{C}-\mathrm{H}$ bonds are more easily cleaved. Therefore, more vacant sites and more $\mathrm{Ce}^{3+}$ ions are expected to form on Co-ceria catalysts as compared to $\mathrm{Ni}$-ceria, in agreement with the experimental observations (Figure 3).

Our results on $\mathrm{M}$-ceria $\{\mathrm{M}=\mathrm{Co}, \mathrm{Ni}, \mathrm{Cu}\}$ model catalysts show that not only the nature of the metal is crucial for DRM activity and system stability, as recently pointed out for $\mathrm{Ni}$, Co and Co-Ni nanoparticles, ${ }^{13,14}$ but also the oxide support can play an essential role. An oxide support can modify the electronic properties of an admetal in substantial ways making its chemical properties very different from those of the corresponding bulk metal. ${ }^{[5,6,15]}$ Single $\mathrm{Co}$ and $\mathrm{Ni}$ atoms on $\mathrm{CeO}_{2}$ interact strongly with the reducible support while adopting a +2 oxidation state, and exhibit room temperature activity for $\mathrm{C}-\mathrm{H}$ bond dissociation. Moreover, reducing the ceria support stabilizes metallic Co and $\mathrm{Ni}$ atoms and the systems are active for methane activation and dry reforming, with $\mathrm{Co}-\mathrm{CeO}_{2-x}$ being much more active than $\mathrm{Ni}$ $\mathrm{CeO}_{2-\mathrm{x}}$. It is also seen that a low metal loading, below $0.2 \mathrm{ML}$, is crucial for the catalyst activity and stability since deactivation due to carbon deposition is observed at higher loading. This is consistent with the calculated trend in the adsorption energy of $\mathrm{C}$ atoms on the supported metal clusters of varying size (Figure $\mathrm{S} 13)$, for example, $\mathrm{Co}_{1} / \mathrm{Ni}_{1}-\mathrm{CeO}_{2}(-4.98 /-4.12)<\mathrm{Co}_{4} / \mathrm{Ni}_{4}-\mathrm{CeO}_{2}(-$ $6.86 /-6.54 \mathrm{eV})$. Here, we show that by choosing the "right" metal-oxide combination and manipulating metal-oxide interactions, as well as controlling the effects of metal loading, an improved catalytic activity can be obtained. Our findings should be useful in the rational design of catalysts for reactions involving $\mathrm{C}-\mathrm{H}$ bond dissociation. Cobalt-ceria can be added to the short list of oxide-based systems that can activate methane at room temperature ${ }^{[6,16]}$ opening the possibility for new and exciting chemistry.

\section{Acknowledgements}

The work carried out at Brookhaven National Laboratory was supported by the US Department of Energy (Chemical Sciences Division, DE-SC0012704). The theoretical work was supported by the MINECO-Spain (CTQ2015-78823-R) and the European Commission Framework 7 project BIOGO (Grant N ${ }^{\circ}$ : 604296). The COST action CM1104 is gratefully acknowledged. Computer time provided by the SGAI-CSIC, CESGA, BIFI-ZCAM, RES, SNCAD (Sistema Nacional de Computación de Alto Desempeño, Arg), ICHEC, and the DECI resources BEM based in Poland at WCSS and Archer at EPCC with support from the PRACE aislb, is acknowledged. M. Vorokhta thanks the Ministry of Education, Youth and Sports of the Czech Republic for financial support under project LH15277.

Keywords: cobalt $\cdot$ ceria $\cdot$ methane dissociation $\cdot$ X-ray photoelectron spectroscopy $\bullet$ density functional theory

[1] Methane in the Environment: Occurence, Uses and Pollution, A. Basile (Editor), Nova Science Publication Inc, 2013

[2] S.I. Chan, S.S.F, Yu, Acc. Chem. Res. 2008, 41, 969-979.

[3] S.I. Chan, Y.-J. Lu, P. Nagababu, S. Maiji, M.-C. Hung, M.M. Lee, I-J. Hsu, P.D. Minh, J.C.H. Lai, K.Y. Ng, S. Ramalingam, S.S.F. Yu, M.K. Chan, Angew. Chem. Int. Ed. 2013, 52, 3731-3735.

[4] J. Xu, A. Zheng, X. Wang, G. Qi, J. Su, J. Du, Z. Gan, J. Wu, W. Wang, F. Deng, Chem. Sci. 2012, 3, 2932-2940.

[5] Z. Liu, D.C. Grinter, P.G. Lustemberg, T.-D. Nguyen-Pan, Y. Zhou, S. Luo, I. Waluyo, E.J. Crumlin, D.J. Stacchiola, J. Zhou, J, Carrasco, H,F. Busnengo, M.V. Ganduglia-Pirovano, S.D. Senanayake, J.A. Rodriguez Angew. Chem. Int. Ed. 2016, 55, 7455-7459.

[6] P.G. Lustemberg, P. J. Ramírez, Z. Liu, R. A. Gutiérrez, D. G. Grinter, J. Carrasco, S. D. Senanayake, J. A. Rodriguez, M. V. Ganduglia-Pirovano, ACS Catal. 2016, 6, 8184-8191.

[7] T. Choudhary, D.W.Goodman, J. Mol. Catal. A-Chem. 2000, 163, 9-18.

[8] a) J. Wei, E. Iglesia, J. Phys. Chem. B, 2004, 108, 4094-4103; b) D. 
Pakhare, J. Spivey, Chem. Soc. Rev. 2014, 43, 7813-7837.

[9] J. Carrasco, L. Barrio, P. Liu, J. A. Rodriguez, M. V. Ganduglia-

Pirovano, J. Phys. Chem. C 2013, 117, 8241-8250.

[10] a) Z. J. Zuo, W. Huang, P. D. Han and Z. H. Li, Appl. Surf. Sci. 2010, 256, 5929-5934; b) X. Hao, Q. Wang, D. Li, R. Zhang, B. Wang, RSC Adv. 2014, 4, 43004-43011.

[11] a)H.-Y. Li, Y.-L. Guo, Y. Guo, G.-Z. Lu, J. Chem. Phys. 2008, 128

051101 ; b) G. Gajewski, C.-W. Pao, J. Chem. Phys. 2011, 135, 064707 c) W. Zhang, P. Wu, Z. Li and J. Yang, J. Phys. Chem. C 2011, 115 17782-17787.

[12] a) F. Abild-Pedersen, O. Lytken, J. Engbak, G. Nielsen, I. Chorkendorff, J. K. Nørskov, Surf. Sci. 2005, 590, 127-137; b) Y.-A. Zhu, D. Chen, X.-G. Zhou, W.-K. Yuan, Catal. Today 2009, 148, 260-267; c) S. Nave, A. K. Tiwari, B. Jackson, J. Chem. Phys. 2010, 132, 054705; d) B Jiang, R. Liu, J. Li, D. Xie, M. Yang, H. Guo, Chem. Sci. 2013, 4, 3249 3254; e) J. Li, E. Croiset, L. Ricardez-Sandoval, Chem. Phys. Lett. 2015, 639, 205-210.

[13] B. AlSabban, L. Falivene, S. M. Kozlov, A. Aguilar-Tapia, S. Ould-Chikh, J.-L. Hazemann, L. Cavallo, J.-M. Basset, K. Takanabe, Applied Catalysis B: Environmental 2017, 213, 177-189.

[14] W. Tu, M. Ghoussoub, C. V. Singh, Y.-H. C. Chin, J. Am. Chem. Soc. 2017, 139, 6928-6945

[15] a) M. Sterrer, T. Risse, U. Martinez Pozzoni, L. Giordano, M. Heyde, H.P. Rust, G. Pacchioni, H.-J. Freund, Phys. Rev. Lett. 2007, 98, 096107; b) A. Bruix, J. A. Rodriguez, P. J. Ramirez, S. D. Senanayake, J. Evans, J. B. Park, D. Stacchiola, P. Liu, J. Hrbek, F. Illas, J. Am. Chem. Soc. 2012, 134, 8968 - 8974; c) V. Simic-Milosevic, M. Heyde, N. Nilius, T Konig, H.P. Rust, M. Sterrer, T. Risse, H.J.Freund, L. Giordano, G. Pacchioni, J. Am. Chem. Soc. 2008, 130, 7814-7815.

[16] a) Z. Liang, T. Li, M. Kim, A. Asthagiri, J.F. Weaver, Science, 2017, 356 299-303; b) C.-C. Wang, S.S. Siao, J.-C. Jiang, J. Phys. Chem. C, 2012, 116, 6367-6370; c) G. Kumar, S.L.J. Lau, M.D. Krcha, M.J. Janik, ACS Catal. 2016, 6, 1812-1821.; d) A.A. Latimer, A.R. Kulkarni, H. Aljama, J.H. Montoya, J.S. Yoo, C. Tsai, F. Abild-Pedersen, F. Studt, J.K. Nørskov , Nature Materials, 2017, 16, 225-229. 
TOC

\section{Text for Table of Contents:}

Low-loaded $\mathrm{Co}-\mathrm{CeO}_{2}$ is a highly efficient, stable and nonexpensive catalyst for methane activation at RT and dry reforming at relative low temperatures $(700 \mathrm{~K})$, as revealed by experiments of ambient pressure XPS in combination with DFT calculations. Ethane/ethylene formation is also observed. Upon temperature increase the $\mathrm{Co}^{2+} / \mathrm{CeO}_{2} \rightarrow \mathrm{Co}^{0} / \mathrm{CeO}_{2-x}$

transformation occurs, making the latter extremely active. The DRM activity strongly depends on the metal-ceria combination, with Co-ceria > Ni-ceria, and $\mathrm{Cu}$-ceria being inactive.

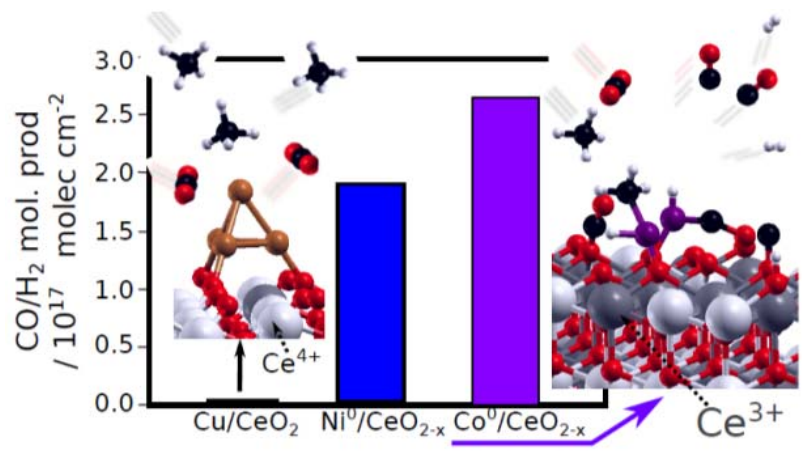




\section{Experimental and Theoretical sections}

\subsection{Experimental Section}

A commercial SPECS AP-XPS chamber equipped with a PHOIBOS 150 EP MCD-9 analyzer was used for the XPS analysis. The AP-XPS chamber can take pressure up to 1 torr with heating capability up to $900 \mathrm{~K}$. The Ce $4 \mathrm{~d}$ photoemission lines were used for the binding energy calibration based on the $122.8 \mathrm{eV}$ satellite feature. To generate the films used to prepare the $\mathrm{MO}_{x} / \mathrm{CeO}_{2}(111) \mathrm{M}=\mathrm{Co}, \mathrm{Ni}$ or $\mathrm{Cu}$ model catalysts, Ce metal was evaporated onto a $\mathrm{Ru}$ single crystal (0001) held at $700 \mathrm{~K}$ in the presence of $5 \times 10^{-7}$ Torr $\mathrm{O}_{2}$, and then annealed to $800 \mathrm{~K}$ for 10 mins at the same $\mathrm{O}_{2}$ pressure.[1,2] The ceria films were estimated to be ca. $4 \mathrm{~nm}$ thick ( 10 layers of $\mathrm{O}-\mathrm{Ce}-\mathrm{O}$ ) based on the attenuation of the $\mathrm{Ru} 3 \mathrm{~d}$ XPS signal. The metals $(\mathrm{Co}, \mathrm{Ni}$ or $\mathrm{Cu}$ ) were vapor deposited on the as-prepared ceria film at $300 \mathrm{~K}$ under vacuum and then annealed to $700 \mathrm{~K}$ for $1 \mathrm{~min}$.[1,2]

The catalytic tests were done in a set-up that combined a chamber for ultra-high vacuum (UHV) studies and a batch reactor. [2] In the studies of methane activation, the sample was transferred to the reactor at $\sim 300 \mathrm{~K}$, and then the reactant gas at 1 Torr of pressure was introduced. In experiments testing the activity of the $\mathrm{MO}_{2}$ / $\mathrm{CeO}_{2}(111)$ catalysts for the DRM process, the samples were exposed to a mixture of $\mathrm{CH}_{4}$ (1 Torr) and $\mathrm{CO}_{2}(1$ Torr) at $300 \mathrm{~K}$ and were rapidly heated to the reaction temperature of $650 \mathrm{~K}$. Product yields were analyzed by mass spectroscopy or chromatography. In our experiments data were collected at intervals of $5 \mathrm{~min}$. The amount of molecules $\left(\mathrm{CO}, \mathrm{H}_{2}\right.$, ethane) produced in the catalytic tests was normalized by the active area exposed by the sample and the total reaction time. The kinetic experiments were done in the limit of low conversion $(<10 \%)$.

\subsection{Theoretical Section}

The spin-polarized calculations were performed using the DFT-(PBE) $+\mathrm{U}$ approach as implemented in the Vienna ab initio simulation package (VASP) \{vasp site, http://www.vasp.at; version vasp.5.3.5\}. A value of 4.5 $\mathrm{eV}$ was used for the Hubbard U-like term. The projector augmented wave method (PAW) was employed at a plane-wave cutoff of $415 \mathrm{eV}$ to decouple the core from valence electrons. The C (2s, 2p), O (2s, 2p), Ni (3p, 3d, $4 \mathrm{~s}), \mathrm{Co}(3 \mathrm{p}, 3 \mathrm{~d}, 4 \mathrm{~s}), \mathrm{Cu}(3 \mathrm{p}, 3 \mathrm{~d}, 4 \mathrm{~s})$ and $\mathrm{Ce}(4 \mathrm{f}, 5 \mathrm{~s}, 5 \mathrm{p}, 5 \mathrm{~d}, 6 \mathrm{~s})$ electrons were treated as valence states.

In order to test the effect of long-range dispersion corrections on the methane adsorption and dissociation, we have selectively used the so called DFT-DF2 approach [3] implemented in VASP by Klimeš et al. [4,5], using the algorithm of Roman-Perez and Soler [6], see Figure S14 below. The DFT-DF2 functional aims to improve the binding description around energy minima by changing both the exchange and non-local correlation components. Specifically, we report results of DFT+U-DF2 (a Hubbard-like U term added) calculations using the so called optB88-vdW functional $[5,6]$, with the DFT(PBE)+U lattice constant.

The $\mathrm{M} / \mathrm{CeO}_{2}(111)$ and $\mathrm{M} / \mathrm{Ce}_{2} \mathrm{O}_{3}(0001)\{\mathrm{M}=\mathrm{Co}$, Ni or $\mathrm{Cu}\}$ surfaces were modeled by $(2 \times 2)$ unit cells, with calculated ceria bulk equilibrium lattice constant $\left(\mathrm{CeO}_{2}: 5.485 \AA ; \mathrm{Ce}_{2} \mathrm{O}_{3}: 5.537 \AA\right)$. In the case of $\mathrm{CeO}_{2}(111)$ we have considered nine atomic layers (three $\mathrm{O}-\mathrm{Ce}-\mathrm{O}$ trilayers) whereas $\mathrm{Ce}_{2} \mathrm{O}_{3}(0001)$ was modeled with fifteen atomic layers (six Ce atomic layers).

There are two allotropic modifications of cobalt; a hexagonal close-packed (HCP) form, stable at temperatures below $422^{\circ} \mathrm{C}$, and a face-centered-cubic (FCC) form, which is stable between $422{ }^{\circ} \mathrm{C}$ and its melting point of $1495^{\circ} \mathrm{C}[7]$. We have considered modeling the $\mathrm{Co}(111)$ and $\mathrm{Co}(0001)$ surfaces because, O'Shea et al. and Zhang et al. in two different experiments have demonstrated that the stable phases of cobalt are very sensitive to their exposed environment such as pressure, temperature and pretreatiment of the catalysts $[8,9]$.

The $\mathrm{Co}(0001), \mathrm{Co}(111)$ and $\mathrm{Cu}(111)$ surfaces were modeled by $(3 \times 3)$ unit cell and five metal layers. The optimized lattice constats for (hcp) $\mathrm{Co}(\mathrm{a}=\mathrm{b}=2.492 \AA$ and $\mathrm{c}=4.028 \AA)$ and (fcc) Co $(\mathrm{a}=3.520 \AA) \mathrm{Cu}(\mathrm{a}=$ $3.635 \AA$ ) agree well with the experimental values (hcp Co: $\mathrm{a}=\mathrm{b}=2.507 \AA$ and $\mathrm{c}=4.061 \AA$ [10], fcc Co: $\mathrm{a}=$ $3.544 \AA$ [10] fcc Cu: $\mathrm{a}=3.597 \AA$ [11]). In all surface models, consecutive slabs were separated by at least $12 \AA$ of vacuum space to avoid interaction with periodic images. Monkhorst-Pack grids with a $(3 \times 3 \times 1)$ and $(5 \times 5$ $\times 1)$ k-point sampling were used for the ceria-based systems and the extended metal surfaces, respectively. All the atoms in the three bottom layers were fixed at their optimized bulk-truncated positions during geometry optimization, whereas the rest of the atoms were allowed to fully relax.

To locate the TS structures we employed the climbing image nudged elastic band method (CI-NEB)[12] with nine images for each reaction pathway. For all the TS reported in this work, we have found only one imaginary frequency, and the full geometry optimizations starting from its back and forward nearest configurations (along the reaction path) ended in a non-dissociated and dissociated state, respectively. 


\section{Results}

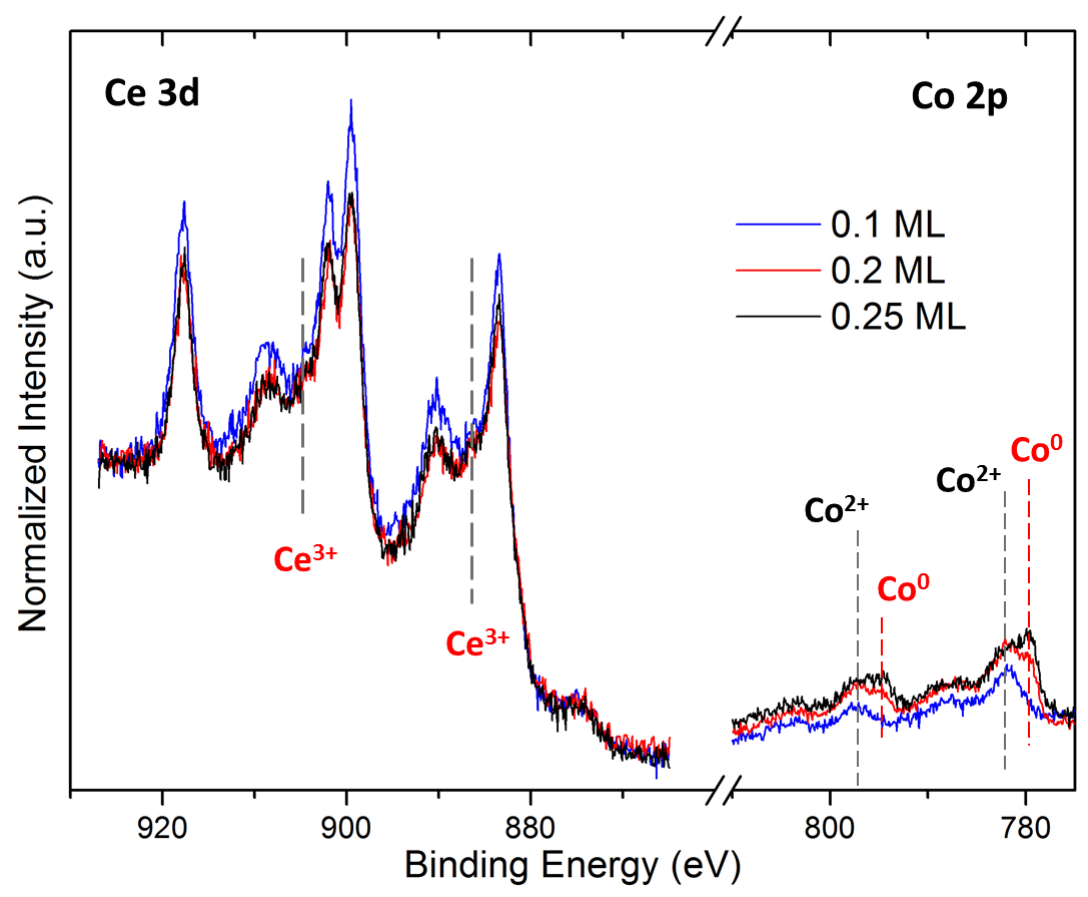

Figure S1: Ce 3d + Co 2p XPS regions of the as-deposited surfaces with increased Co coverages from $0.1,0.2$ to $0.25 \mathrm{ML}$.

Figure $\mathrm{S} 1$ shows the coverage dependency of Co growth on $\mathrm{CeO}_{2}(111)$ surface. The spectra were taken at $300 \mathrm{~K}$ before annealing. It can be seen that, even at $300 \mathrm{~K}$, a small amount of Co already interacts strongly with the ceria substrate, resulting in the formation of $\mathrm{Co}^{2+}$. (In XPS is hard to distinguish $\mathrm{Co}^{2+}$ from $\mathrm{Co}^{3+}$, but $\mathrm{Co}^{3+}$ probably will not form under these conditions). As the Co coverage increased, the intensities of $\mathrm{Co}^{2+}$ peaks have saturated, and the metallic Co features start to develop, indicating Co particles are growing three dimensionally at this point. At the same time, ceria is slightly reduced as shown by the $\mathrm{Ce}^{3+}$ features in the figure. 


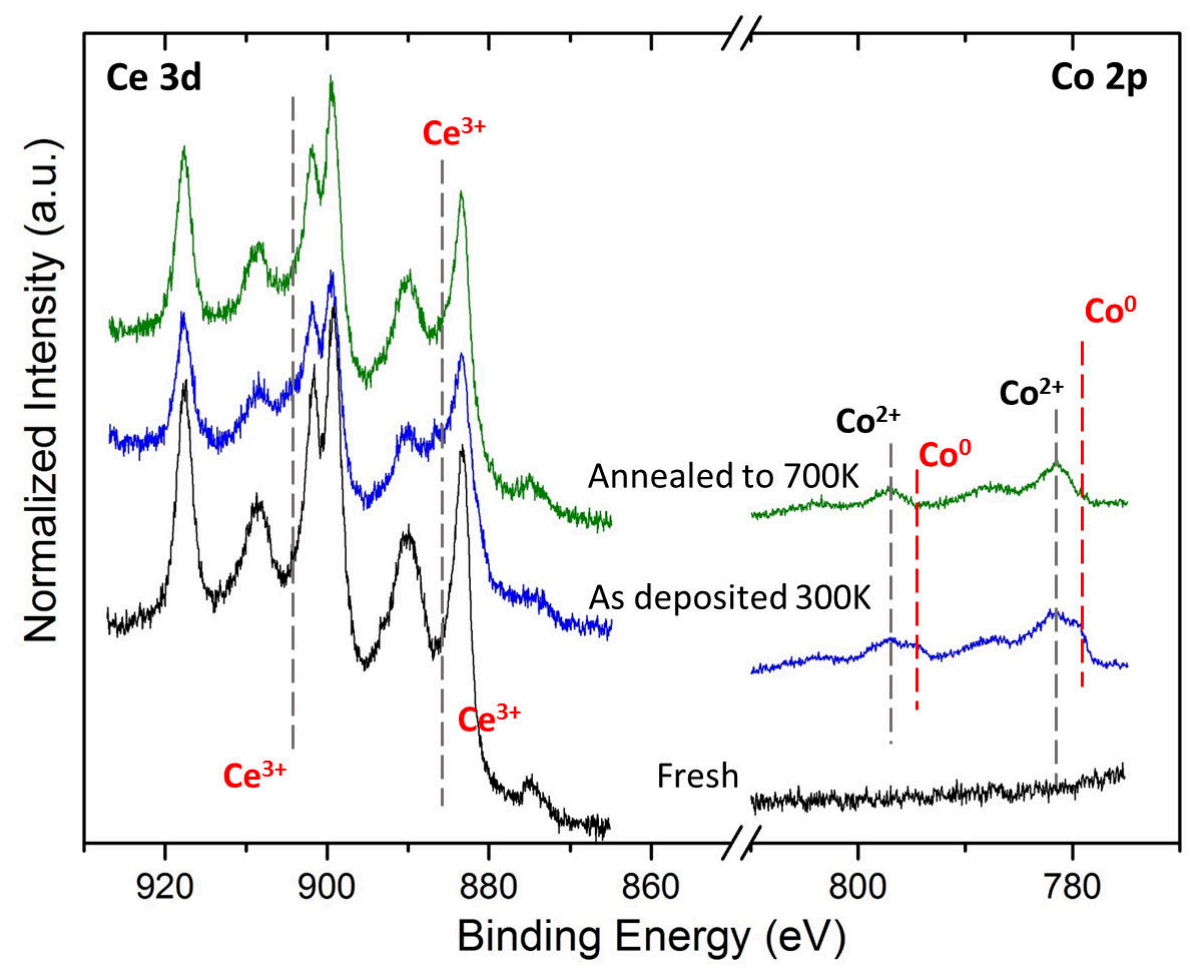

Figure S2: Ce $3 \mathrm{~d}+$ Co $2 \mathrm{p}$ XPS spectra of the surfaces before/after annealing, $\theta_{C o} \approx 0.2 \mathrm{ML}$.

After depositing Co at $300 \mathrm{~K}$, the surface was annealed to $700 \mathrm{~K}$ in UHV to generate a stabilized surface before any surface chemistry was studied. The surfaces before/after annealing are compared in Figure S2. One can see that the metallic Co feature is gone as annealing allows more charge transfer/oxygen spillover from ceria to cobalt. Interestingly, the ceria film was also slightly re-oxidized, probably due to the diffusion of the lattice oxygen from sublayers to the surface by annealing. 


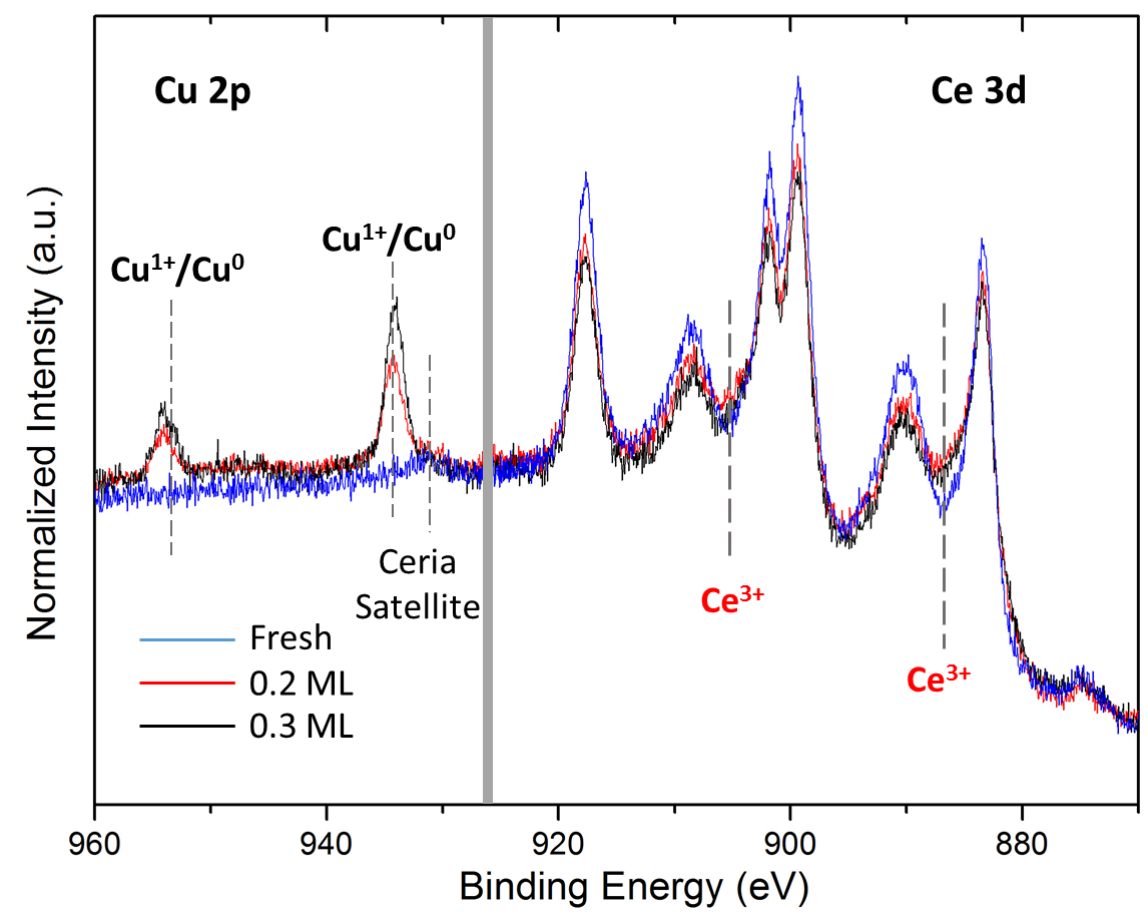

Figure S3: Ce 3d + Cu 2p XPS regions of the fresh surface (blue), as-deposited surfaces with $0.2 \mathrm{ML}$ (red) and $0.3 \mathrm{ML} \mathrm{Cu}$ (black) coverages, respectively.

XPS data collected at $300 \mathrm{~K}$ before annealing the $\mathrm{Cu} /$ ceria systems. Ceria is slightly reduced after $\mathrm{Cu}$ deposition while most of the $\mathrm{Cu}$ is oxidized to $\mathrm{Cu}^{1+}$, as indicated by the Auger spectrum. No changes are seen with increased $\mathrm{Cu}$ coverage.

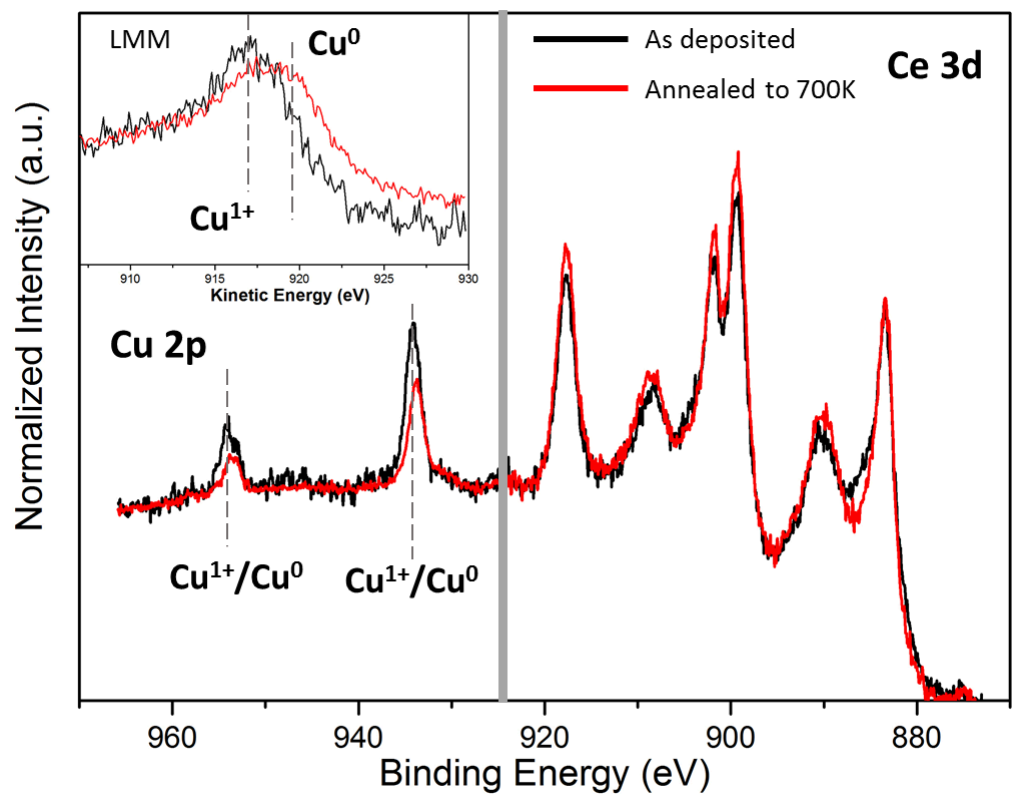

Figure S4: Ce $3 \mathrm{~d}+\mathrm{Cu} 2 \mathrm{p}$ XPS spectra of the surfaces before/after annealing, $\theta_{C o} \approx 0.3 \mathrm{ML}$

In contrast to the Co deposited surface, annealing the $\mathrm{Cu} / \mathrm{CeO}_{2}(111)$ surfaces leads to the reduction of $\mathrm{Cu}^{1+}$ to $\mathrm{Cu}^{0}$, as evident by the Auger spectrum in the inset figure. One possible explanation is that the severe 
coalescence of $\mathrm{Cu}$ after annealing causes the reduction of $\mathrm{Cu}$, which is a strong indication that the interaction between $\mathrm{Cu}$ with $\mathrm{CeO}_{2}(111)$ is much weaker than in the case of Co.

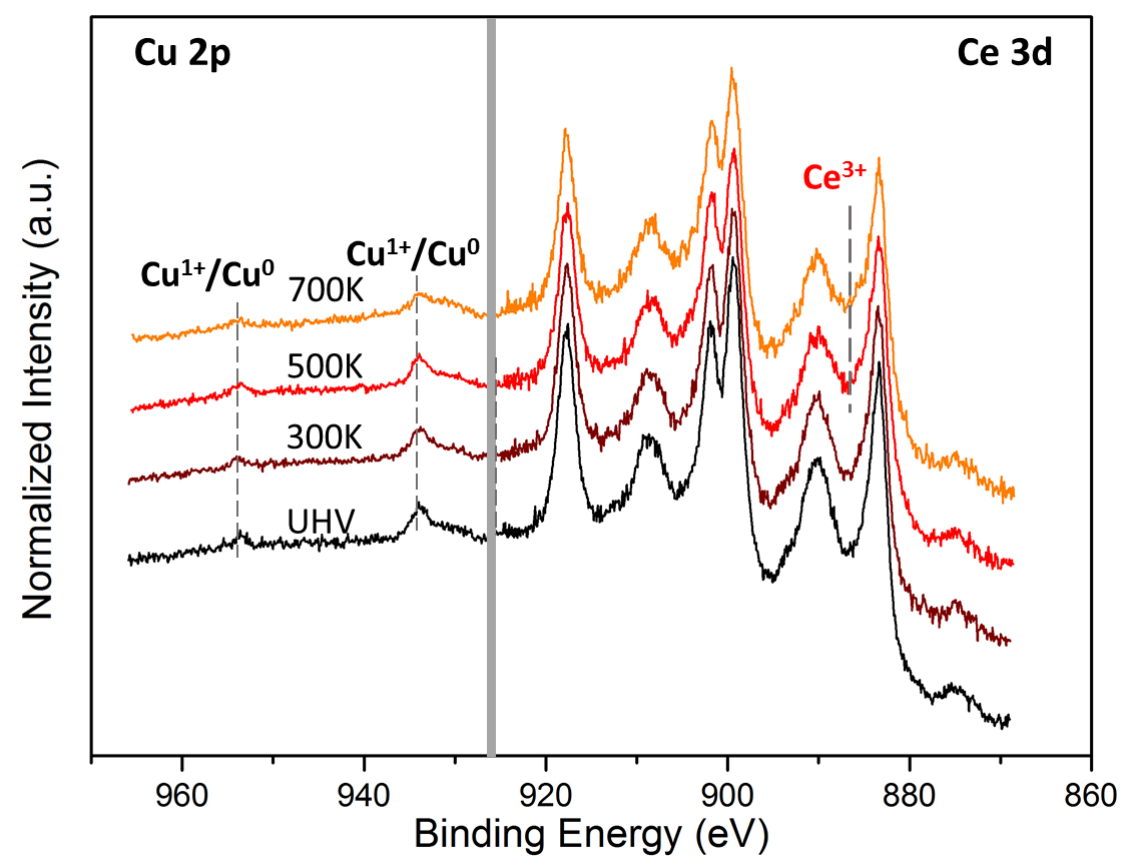

Figure S5: Ce $3 \mathrm{~d}+\mathrm{Cu} 2 \mathrm{p}$ XPS spectra of the surface at elevated temperatures under 50 mTorr $\mathrm{CH} 4, \theta_{C o} \approx 0.2 \mathrm{ML}$.

No changes for $\mathrm{Cu}$-ceria surfaces under 50 mTorr of methane.

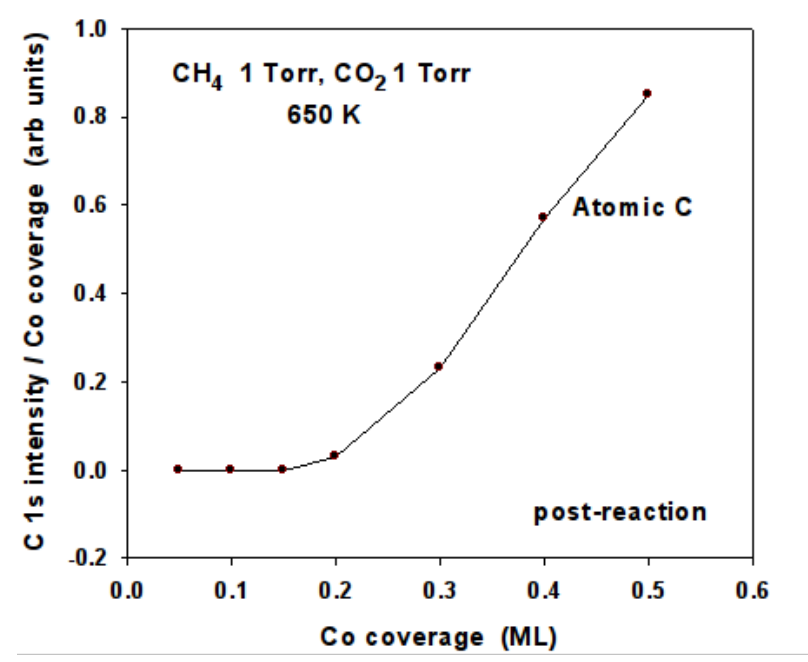

Figure S6: Effect of Co coverage on the amount of atomic carbon (features in the 284-282 $\mathrm{eV}$ window) formed after exposing $\mathrm{Co}-\mathrm{CeO}_{2}(111)$ surfaces to 1 Torr of methane and 1 Torr of $\mathrm{CO}_{2}$ at $650 \mathrm{~K}$ for 5 min.

The $\mathrm{C}$ 1s intensity of $\mathrm{C}_{x}$ species was normalized by the coverage of Co on the surface. 
a)
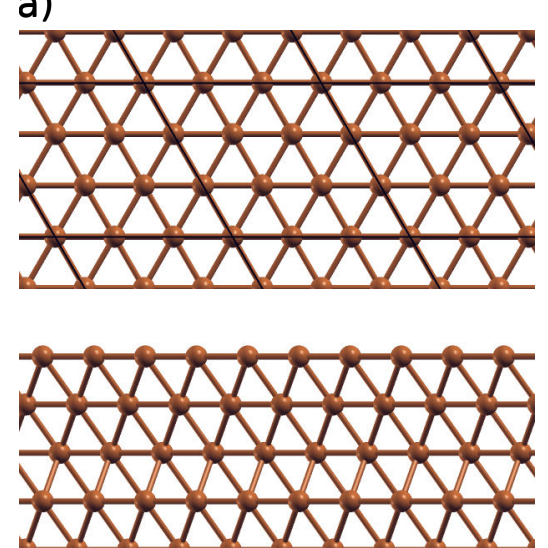

d)

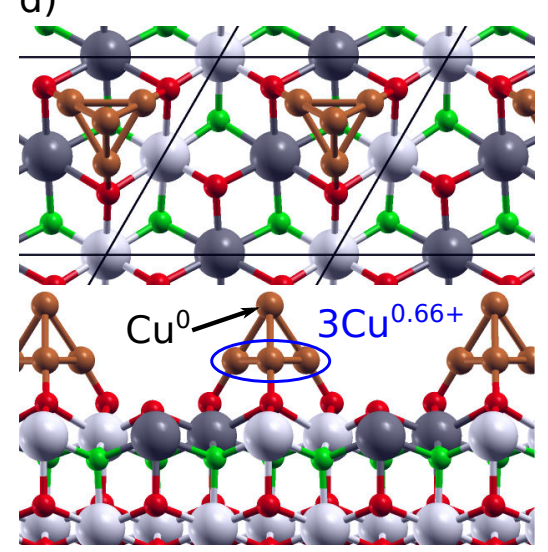

b)

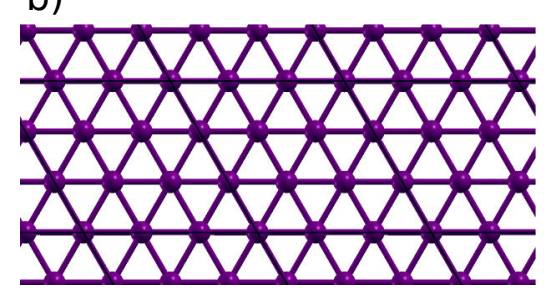

c)
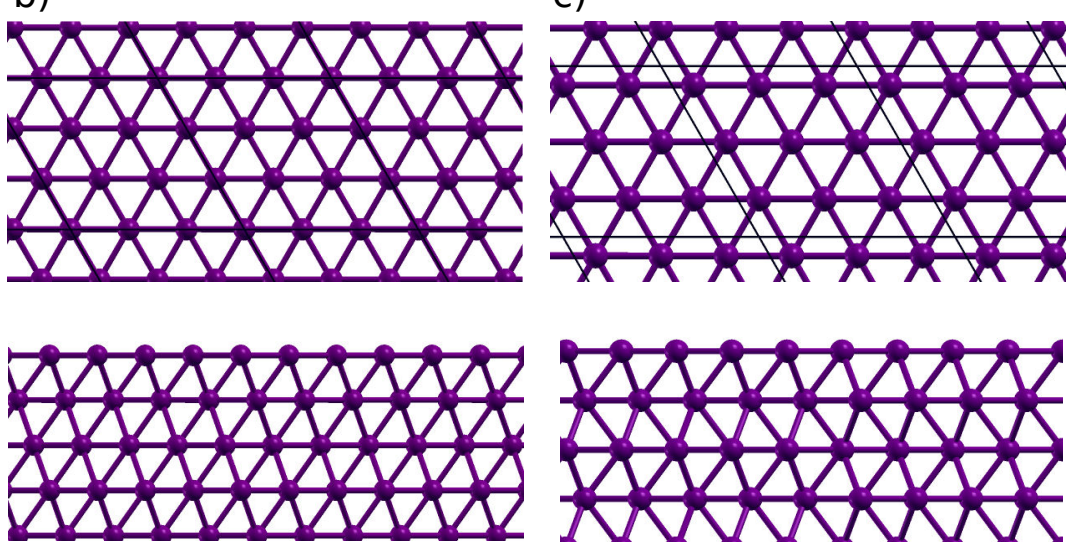

e)

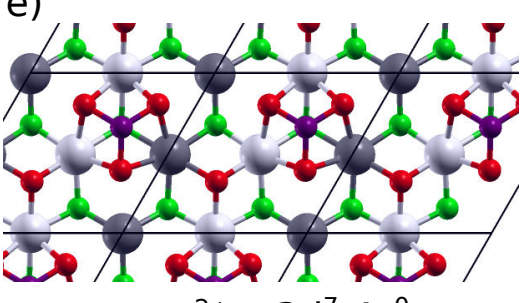

f)
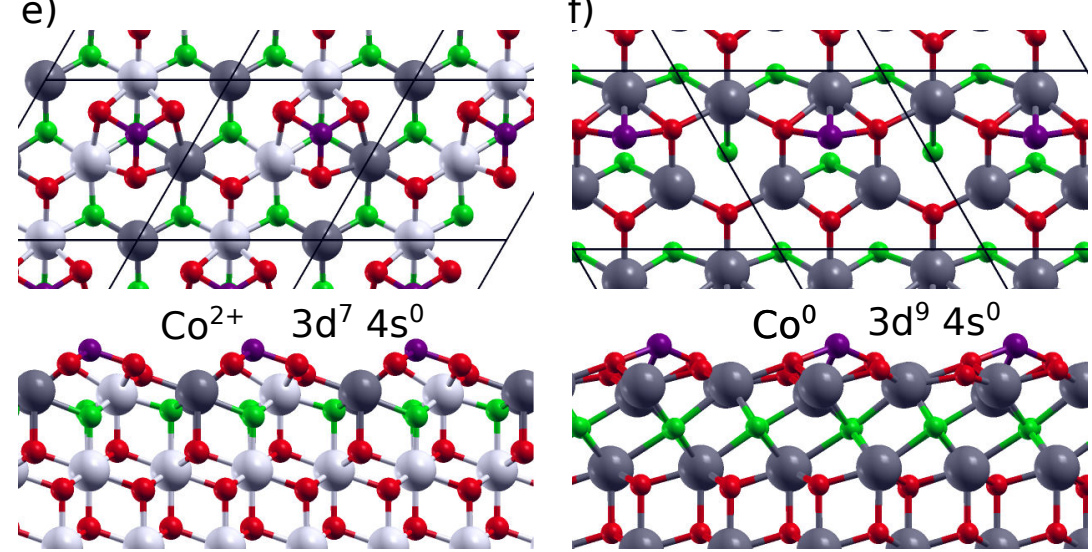

$\mathrm{Co}^{0} 3 \mathrm{~d}^{9} 4 \mathrm{~s}^{0}$

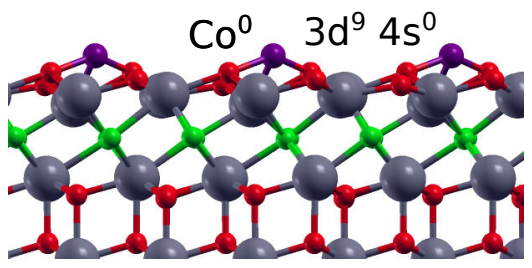

Figure S7: Top and side views of the model catalysts used in the calculations: a) $\mathrm{Cu}(111)$, b) $\mathrm{Co}(111)$ c) $\mathrm{Co}(0001)$, d) $\mathrm{Cu}_{4} / \mathrm{CeO}_{2}(111)$, e) $\mathrm{Co}^{2+} / \mathrm{CeO}_{2}(111)$ and f) $\mathrm{Co}^{0} / \mathrm{Ce}_{2} \mathrm{O}_{3}(0001)$. 

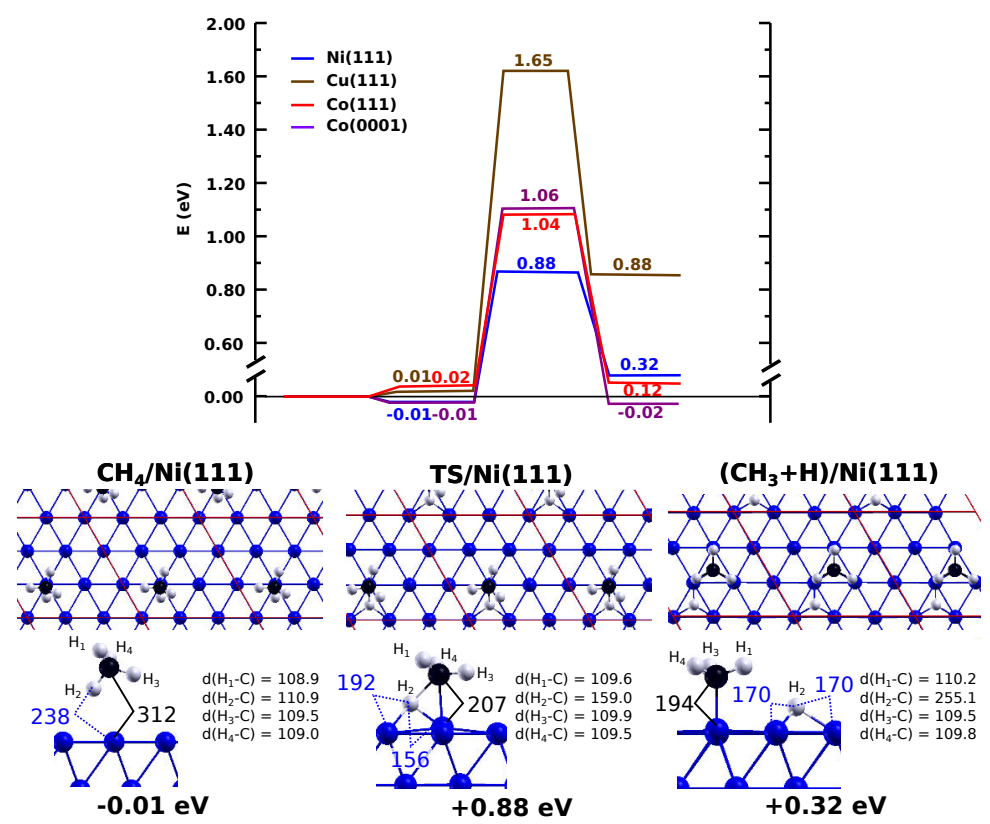

$\mathrm{CH}_{4} / \mathrm{Cu}(111)$

TS/Cu(111)

$\left(\mathrm{CH}_{3}+\mathrm{H}\right) / \mathrm{Cu}(111)$
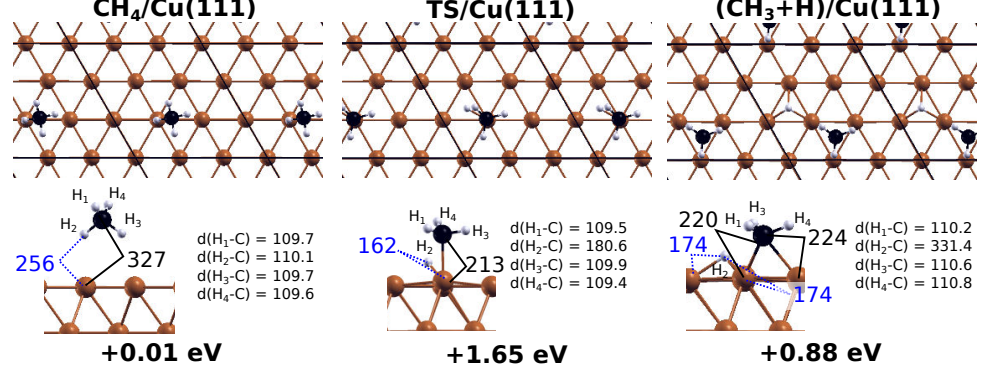

$+1.65 \mathrm{eV}$

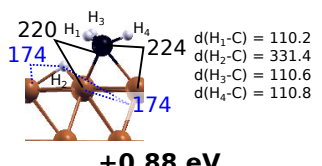

$\mathrm{CH}_{4} / \mathrm{Co}(111)$

TS/Co(111)

$+0.88 \mathrm{eV}$
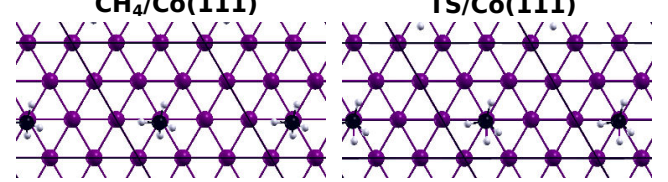

$\left(\mathrm{CH}_{3}+\mathrm{H}\right) / \mathrm{Co}(111)$
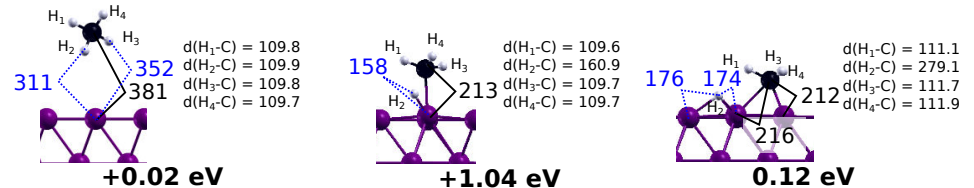

$\mathrm{CH}_{4} / \mathrm{Co}(0001)$ TS/Co(0001) $\left(\mathrm{CH}_{3}+\mathrm{H}\right) / \mathrm{Co}(0001)$
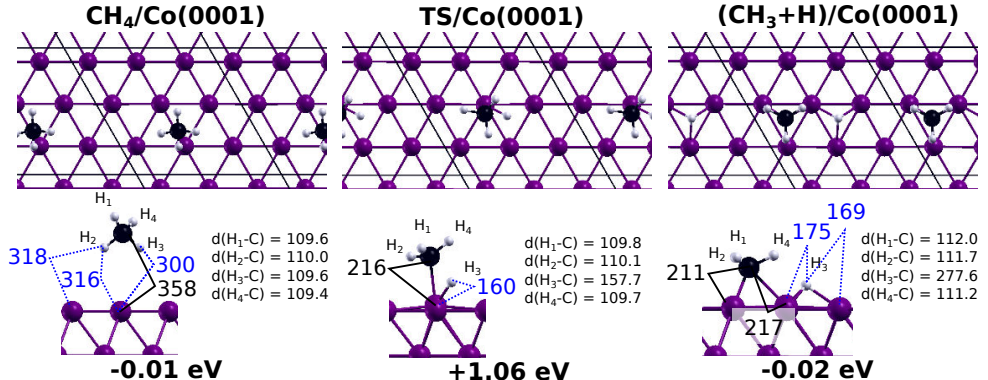

Figure S8: Reaction pathways for $\mathrm{CH}_{4}$ dissociation on $\mathrm{Ni}(111), \mathrm{Cu}(111), \mathrm{Co}(111)$ and $\mathrm{Co}(0001)$ as well as top and side views of the structures of the molecularly adsorbed state, transition state (TS), and dissociated state for the three reaction pathways. Selected interatomic distances (in $\mathrm{pm}$ ) are indicated. All energies (in $\mathrm{eV}$ ) are referenced to the total energy of $\mathrm{CH}_{4}(\mathrm{~g})$ and the extended metal surfaces. 

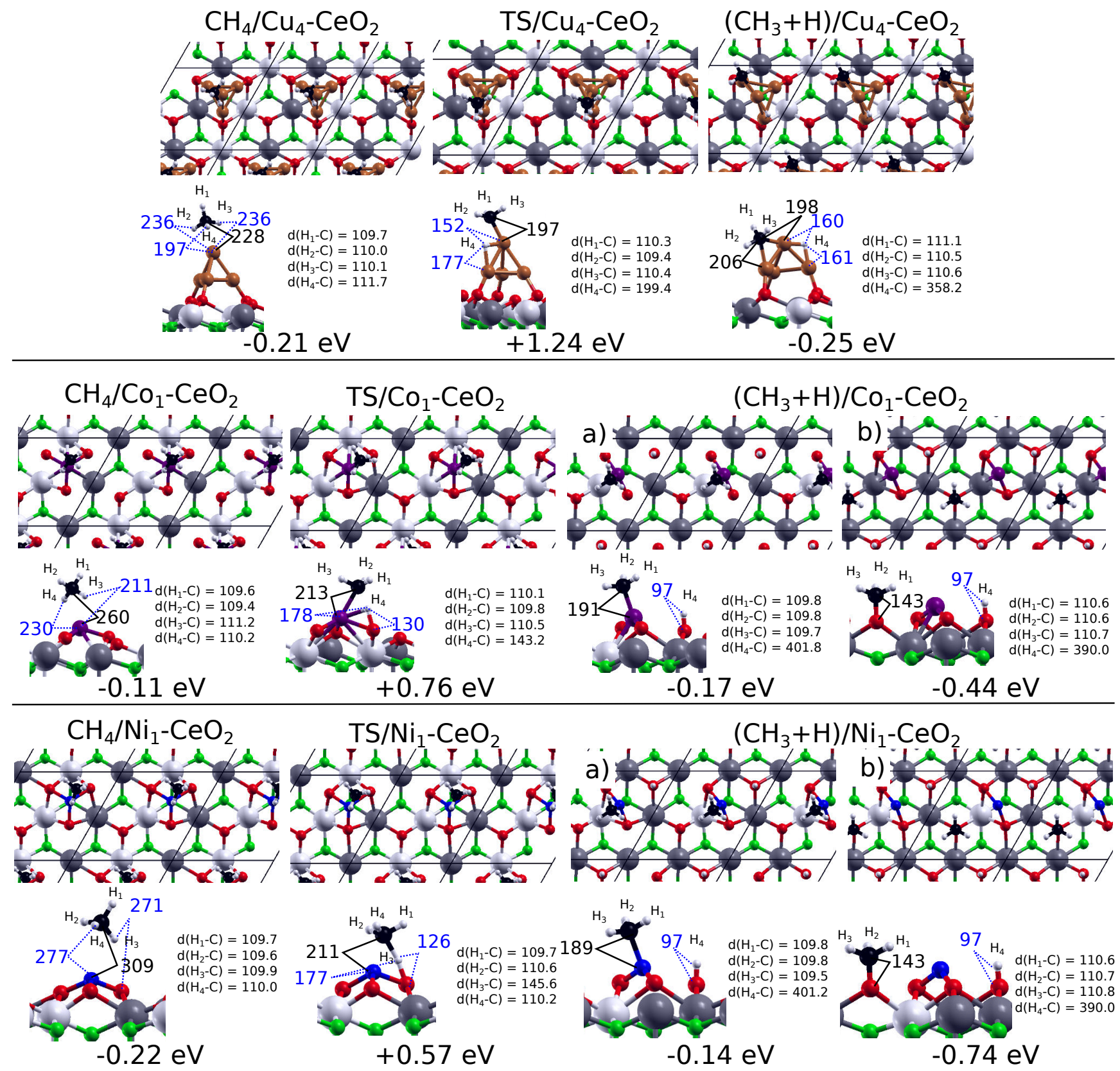

Figure S9: Top and side views of the molecularly adsorbed state, transition state (TS), and dissociated state for the $\mathrm{CH}_{4} \rightarrow \mathrm{CH}_{3}+\mathrm{H}$ reaction on the $\mathrm{Cu}_{4} / \mathrm{CeO}_{2}(111), \mathrm{Co}_{1} / \mathrm{CeO}_{2}(111)$, and $\mathrm{Ni}_{1} / \mathrm{CeO}_{2}(111)$ model catalysts (Figure $7 \mathrm{a}$ in the main text). Selected interatomic distances (in $\mathrm{pm}$ ) are indicated. All energies (in $\mathrm{eV}$ ) are referenced to the total energy of $\mathrm{CH}_{4}(\mathrm{~g})$ and the $\mathrm{M} / \mathrm{CeO}_{2}(111)\{\mathrm{M}=\mathrm{Cu}, \mathrm{Co}, \mathrm{Ni}\}$ surfaces. 

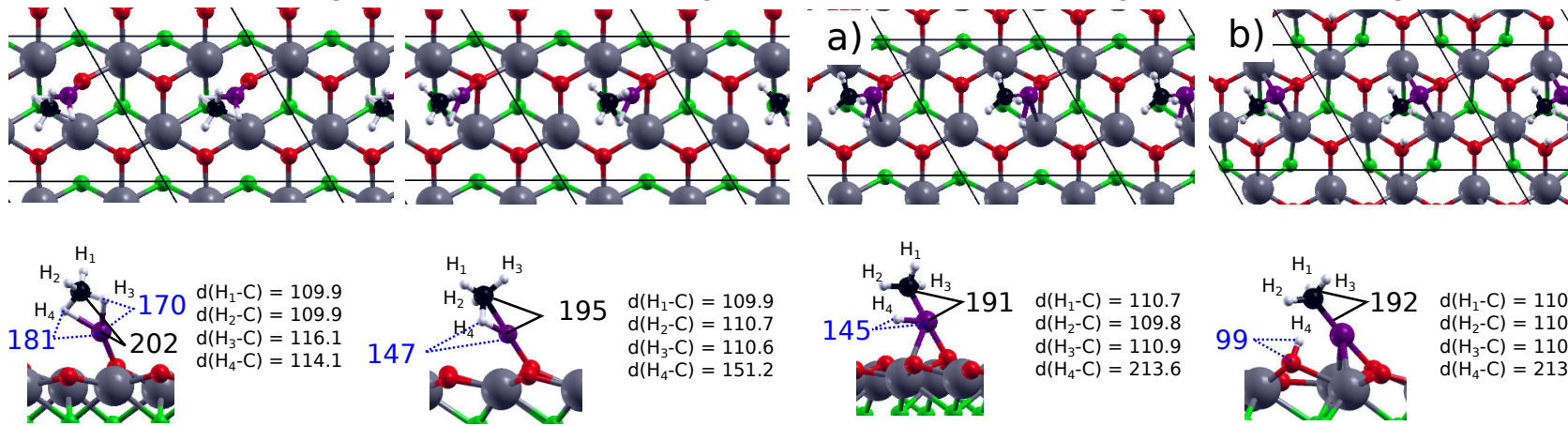

$d\left(\mathrm{H}_{1}-\mathrm{C}\right)=109.9$
$\mathrm{~d}\left(\mathrm{H}_{2}-\mathrm{C}\right)=110.7$
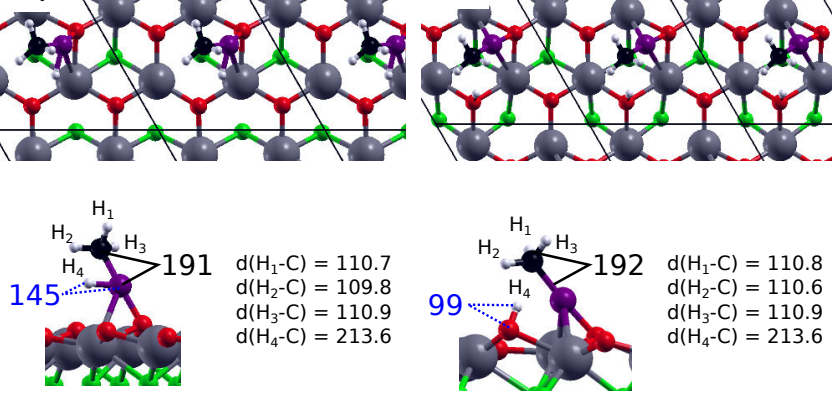

$-0.33 \mathrm{eV}$

$-0.28 \mathrm{eV}$

$-0.38 \mathrm{eV}$

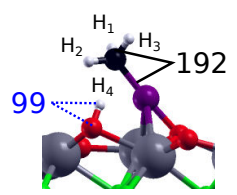

$\left(\mathrm{H}_{1}-\mathrm{C}\right)=110.8$ $\mathrm{d}\left(\mathrm{H}_{2}-\mathrm{C}\right)=110.6$ $d\left(\mathrm{H}_{3}-\mathrm{C}\right)=110.9$ $\mathrm{d}\left(\mathrm{H}_{4}-\mathrm{C}\right)=151.2$

\section{$\mathrm{CH}_{4} / \mathrm{Ni}_{1}-\mathrm{Ce}_{2} \mathrm{O}_{3}$ \\ $\mathrm{TS} / \mathrm{Ni}_{1}-\mathrm{Ce}_{2} \mathrm{O}_{3}$}
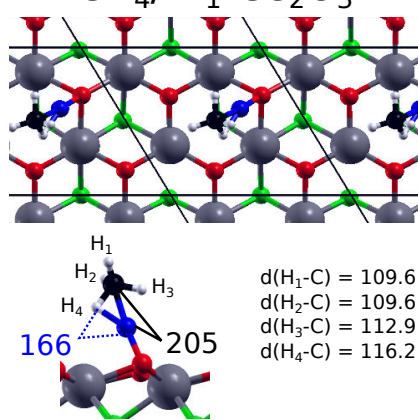

$-0.72 \mathrm{eV}$

$\mathrm{d}\left(\mathrm{H}_{2}-\mathrm{C}\right)=109.6$

$\mathrm{d}\left(\mathrm{H}_{3}-\mathrm{C}\right)=112.9$
$\mathrm{~d}\left(\mathrm{H}_{4}-\mathrm{C}\right)=116.2$
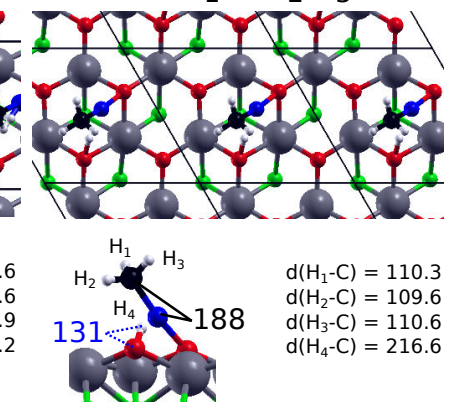

$+0.06 \mathrm{eV}$

$\mathrm{d}\left(\mathrm{H}_{1}-\mathrm{C}\right)=110.3$

$\mathrm{d}\left(\mathrm{H}_{2}-\mathrm{C}\right)=109.6$

$d\left(\mathrm{H}_{3}-\mathrm{C}\right)=110.6$

Figure S10: Top and side views of the molecularly adsorbed state, transition state (TS), and dissociated state for the $\mathrm{CH}_{4} \rightarrow \mathrm{CH}_{3}+\mathrm{H}$ reaction on the $\mathrm{Co}_{1} / \mathrm{Ce}_{2} \mathrm{O}_{3}(0001)$ and $\mathrm{Ni}_{1} / \mathrm{Ce}_{2} \mathrm{O}_{3}(0001)$ model catalysts (Figure $7 \mathrm{~b}$ in the main text). Selected interatomic distances (in $\mathrm{pm}$ ) are indicated. All energies (in $\mathrm{eV}$ ) are referenced to the total energy of $\mathrm{CH}_{4}(\mathrm{~g})$ and the $\mathrm{M} / \mathrm{Ce}_{2} \mathrm{O}_{3}(0001)\{\mathrm{M}=\mathrm{Co}, \mathrm{Ni}\}$ surfaces. 
Table S1: Bader charge change for the $\mathrm{C}$ atom upon $\mathrm{CH}_{4}$ adsorption on ceria and metal-ceria surfaces, with respect to the gas-phase molecule (note: a positive change denote a higher electron density).

\begin{tabular}{cccccc}
\hline $\mathrm{CeO}_{2}(111)$ & $\mathrm{Ni}_{1}^{2+} / \mathrm{CeO}_{2}(111)$ & $\mathrm{Co}_{1}^{2+} / \mathrm{CeO}_{2}(111)$ & $\mathrm{Ce}_{2} \mathrm{O}_{3}(0001)$ & $\mathrm{Ni}_{1}^{0} / \mathrm{Ce}_{2} \mathrm{O}_{3}(0001)$ & $\mathrm{Co}_{1}^{0} / \mathrm{Ce}_{2} \mathrm{O}_{3}(0001)$ \\
\hline-0.03 & -0.09 & +0.03 & -0.01 & +0.15 & +0.16
\end{tabular}

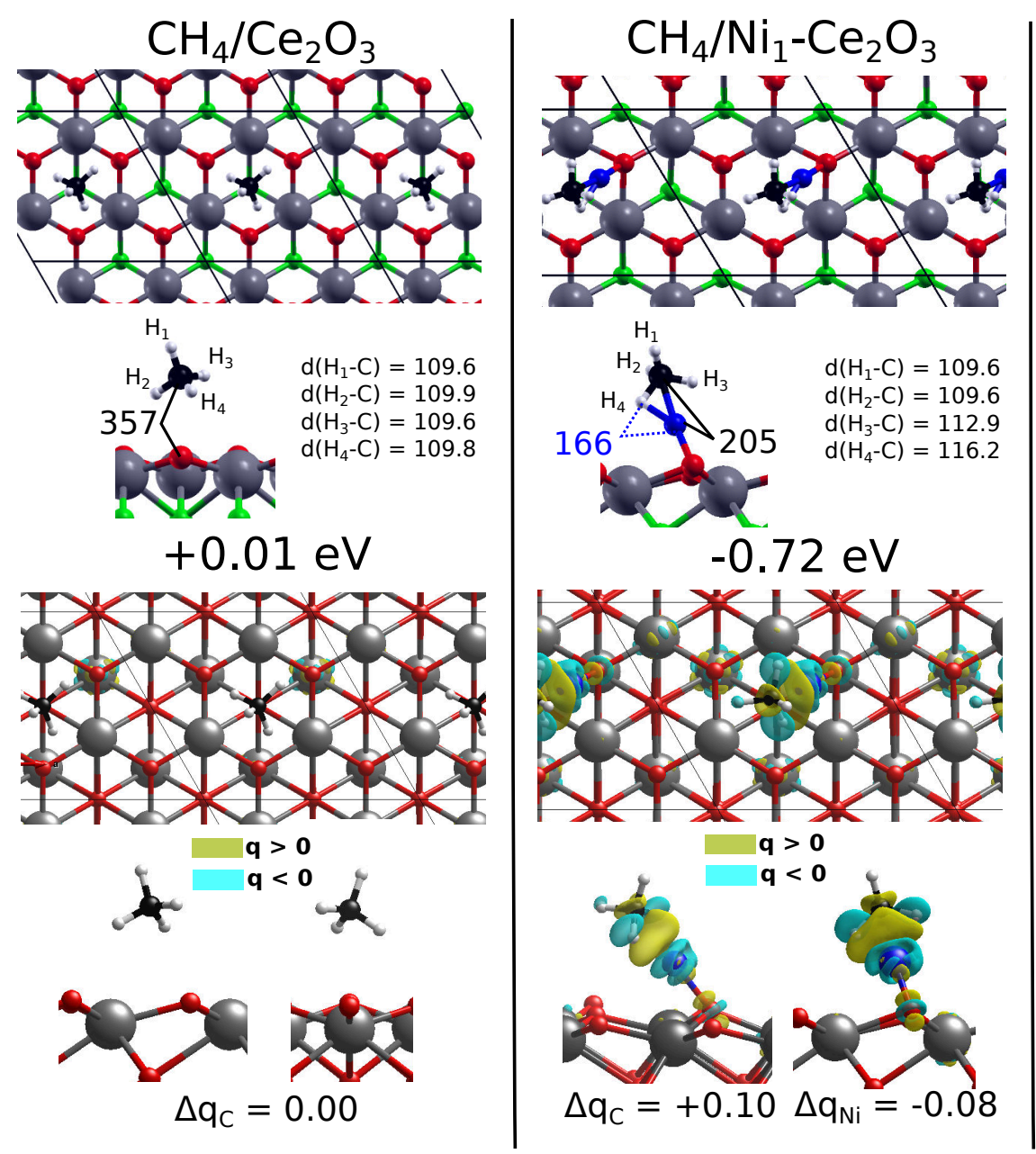

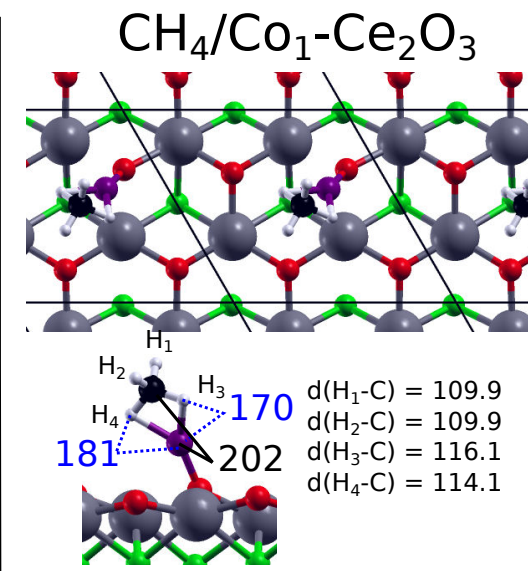
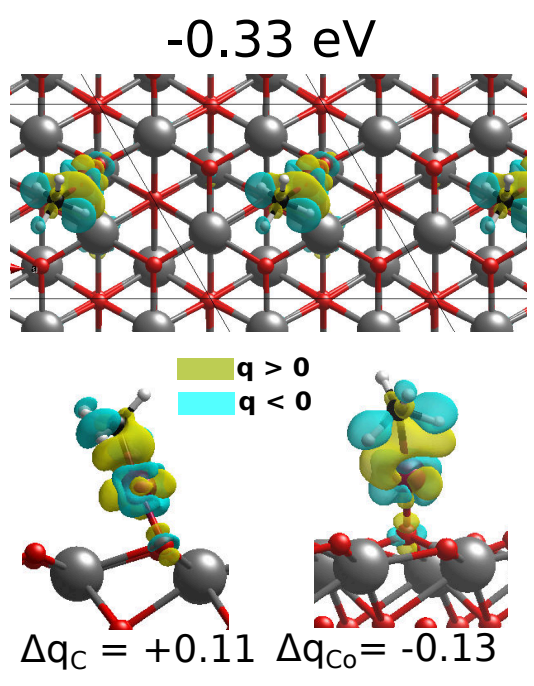

Figure S11: Top panel: Top and side views of molecularly adsorbed $\mathrm{CH}_{4}$ on the $\mathrm{Ce}_{2} \mathrm{O}_{3}(0001), \mathrm{Ni}^{0} / \mathrm{Ce}_{2} \mathrm{O}_{3}(0001)$, and $\mathrm{Co}^{0} / \mathrm{Ce}_{2} \mathrm{O}_{3}(0001)$ surfaces. Selected interatomic distances (in pm) are indicated. Adsorption energies (in $\mathrm{eV}$ ) are referenced to the total energy of $\mathrm{CH}_{4}(\mathrm{~g})$ and the $\mathrm{M} / \mathrm{Ce}_{2} \mathrm{O}_{3}(0001)\{\mathrm{M}=\mathrm{Ni}$, Co $\}$ surfaces. Lower panel: Charge density isosurfaces corresponding to a charge density difference, namely, that of the chemisorbed system from which both the charge density of the clean surface and that of the isolated methane molecule (both with distances as in the chemisorbed system) have been subtracted. $\Delta q$ is the associated Bader charge difference (in electrons). The picture displays the induced effect by the adsorption of a $\mathrm{CH}_{4}$ molecule on the valence charge of its neighboring metal atom on the $\mathrm{M} / \mathrm{Ce}_{2} \mathrm{O}_{3}(0001)\{\mathrm{M}=\mathrm{Ni}, \mathrm{Co}\}$ surfaces, namely, charge is withdrawn from the metal upon $\mathrm{CH}_{4}$ adsorption. 


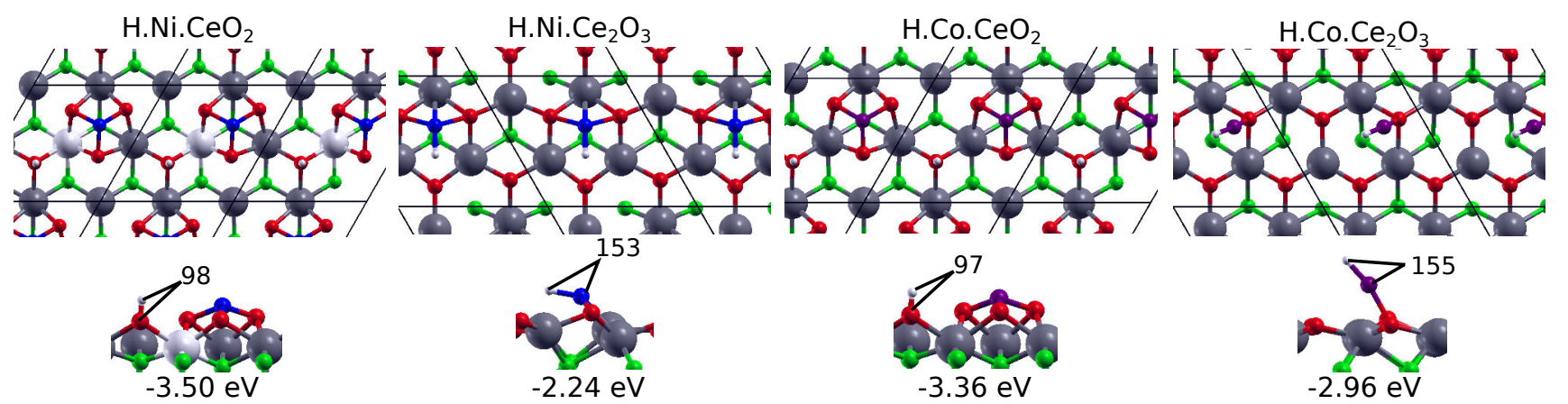

Figure S12: Top and side views of a hydrogen atom adsorbed on the $\mathrm{M}_{1} / \mathrm{CeO}_{2}(111)$ and $\mathrm{M}_{1} / \mathrm{Ce}_{2} \mathrm{O}_{3}(0001)\{\mathrm{M}=\mathrm{Ni}$, Co $\}$ surfaces. Selected interatomic distances (in pm) are indicated. Adsorption energies (in $\mathrm{eV}$ ) are referenced to the total energy of $\mathrm{H}_{2}(\mathrm{~g})$ and the $\mathrm{M} / \mathrm{Ce}_{2} \mathrm{O}_{3}(0001)\{\mathrm{M}=\mathrm{Ni}, \mathrm{Co}\}$ surfaces.
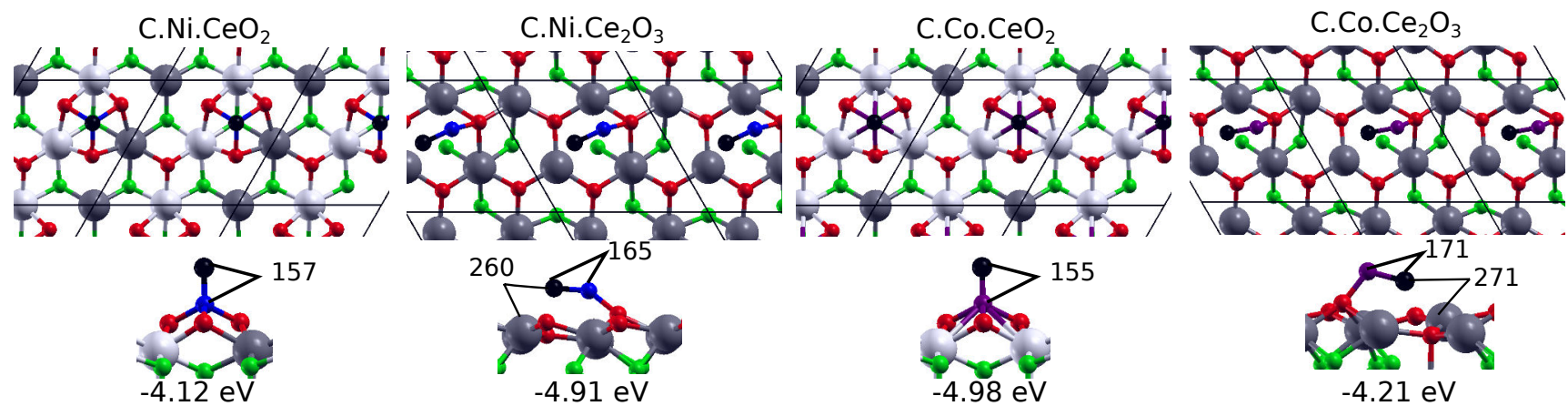

C. $\mathrm{Ni}_{4} \cdot \mathrm{CeO}_{2}$

C. $\mathrm{Ni}_{4} \cdot \mathrm{Ce}_{2} \mathrm{O}_{3}$

C. $\mathrm{CO}_{4} \cdot \mathrm{CeO}_{2}$

C. $\mathrm{CO}_{4} \cdot \mathrm{Ce}_{2} \mathrm{O}_{3}$
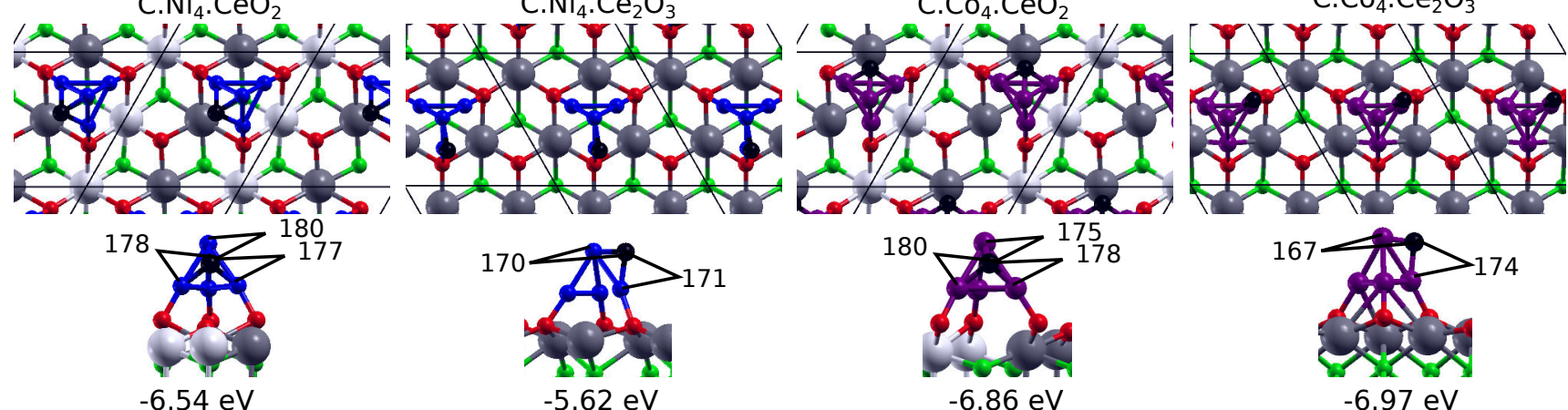

Figure S13: Top and side views of a carbon atom adsorbed on the $\mathrm{M}_{i} / \mathrm{CeO}_{2}(111)$ and $\mathrm{M}_{i} / \mathrm{Ce}_{2} \mathrm{O}_{3}(0001)\{\mathrm{M}=\mathrm{Ni}, \mathrm{Co}, i=1,4\}$ surfaces. Selected interatomic distances (in pm) are indicated. Adsorption energies (in $\mathrm{eV}$ ) are referenced to the total energy of $\mathrm{H}_{2}(\mathrm{~g})$ and the $\mathrm{M} / \mathrm{Ce}_{2} \mathrm{O}_{3}(0001)\{\mathrm{M}=\mathrm{Ni}, \mathrm{Co}\}$ surfaces. 


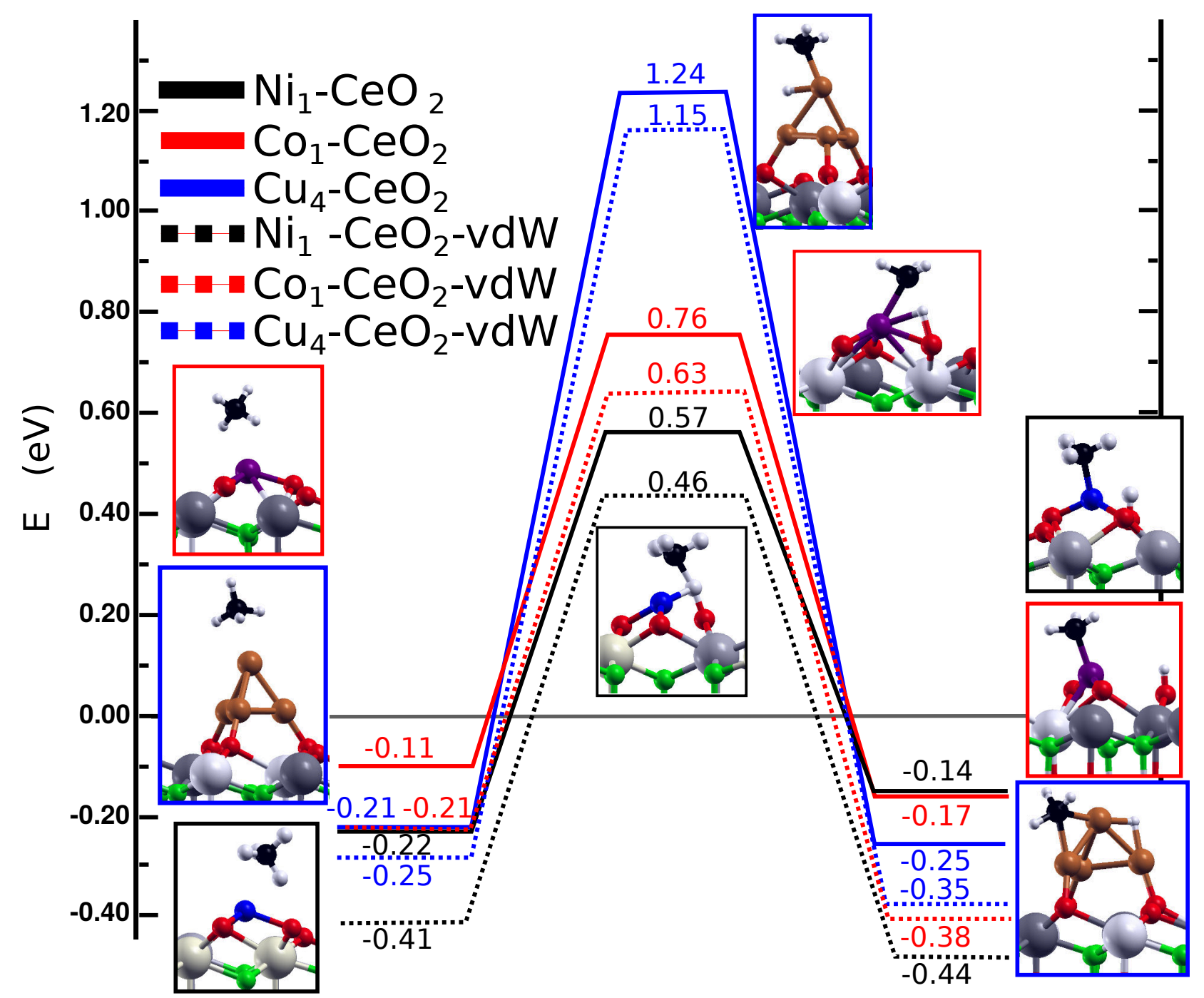

Figure S14: Reaction energy profile for the $\mathrm{CH}_{4} \longrightarrow \mathrm{CH}_{3}+\mathrm{H}$ reaction on $\mathrm{Cu}_{4}, \mathrm{Co}_{1}$ and $\mathrm{Ni}_{1}$ on $\mathrm{CeO}_{2}(111)$ with and without van der Waals corrections. The structures shown on the left, middle and right of the reaction pathways, correspond to the side views of the molecular adsorbed, transition and dissociated states, respectively without vdW correction. All energies are referenced to the total energy of $\mathrm{CH}_{4}(\mathrm{~g})$ and the $\mathrm{M} /$ ceria $\mathrm{M}=\mathrm{Co}, \mathrm{Ni}$, $\mathrm{Cu}$ surfaces. Atoms color scheme: $\mathrm{Ni}$ in blue, $\mathrm{Cu}$ in brown, $\mathrm{Co}$ in violet, $\mathrm{Ce}^{3+}$ in grey, $\mathrm{Ce}^{4+}$ in white, surface/subsurface oxygen atoms in red/green.

\section{Bibliography}

[1] Z. Liu et al, Angew. Chem. Int. Ed. 2016, 55, 7455-7459.

[2] P.G. Lustemberg et al, ACS Catal. 2016, 6, 8184-8191.

[3] Lee, K.; Murray, E. D.; Kong, L.; Lundqvist, B. I.; Langreth, D. C. Phys. Rev. B 2010, 82, 081101.

[4] J. Klimeš, D. R. Bowler, and A. Michaelides, J. Phys.: Cond. Matt. 2010 22, 022201.

[5] J. Klimeš, D. R. Bowler, and A. Michaelides, Phys. Rev. B 2011 83, 195131.

[6] G. Román-Pérez, J. M. Soler, Phys. Rev. Lett. 2009 103, 096102.

[7] W.O. Soboyejo, T.S. Srivatsan, Advanced Structural Materials: Properties, Design Optimization, and Applications, CRC Press, Boca Raton, FL, 2007

[8]V.A. Pena O Shea, P.R. Piscina, N. Homs, G. Aromı, J.L.G. Fierro, Chem. Mater. $200921,5637$.

[9]B.B. Zhang, H. Su,X. Gu, Y. Zhang, P. Wang, X. Li, X. Zhang, H. Wang, X. Yanga and S. Zeng, Catalysis 
Science and Technology 2013 3, 2639.

[10] Lide, D.R., Kehiaian, H.V., Eds. CRC Handbook of Thermophysical and Thermochemical Data; CRC Press: Boca Raton, FL, 1994.

[11] Davey, Wheeler P., Phys. Rev. 1925, 6, 753-761.

[12] G. Henkelman, B. P. Uberuaga, H. Jónsson, J. Chem. Phys. 2000 113, 9901 - 9904. 